\title{
Emission factors of air pollutants from vehicles measured inside road tunnels in São Paulo: case study comparison
}

\author{
P. J. Pérez-Martínez $\cdot$ R. M. Miranda $\cdot$ \\ T. Nogueira $\cdot$ M. L. Guardani $\cdot$ A. Fornaro $\cdot$ \\ R. Ynoue $\cdot$ M. F. Andrade
}

Received: 4 December 2013/Revised: 28 February 2014/ Accepted: 17 March 2014/Published online: 9 April 2014

(C) Islamic Azad University (IAU) 2014

\begin{abstract}
Burning of fuels from the transport sector is one of the main sources of air pollutants emission in urban areas. In order to implement public policies concerning air quality and public health, there is a need to develop emission inventories. Measurements inside traffic tunnels can provide an evaluation of emission factors of vehicles in-use in real conditions. In this paper, we show measurements of air pollutants for a mixed vehicle fleet, heavyand light-duty vehicles (HDVs and LDVs), in two tunnels in the metropolitan region of Sao Paulo in 2011 in order to calculate the pollutant emission factors (EFs). Measurements of carbon dioxide, carbon monoxide (CO), nitrogen oxides $\left(\mathrm{NO}_{\mathrm{x}}\right)$ and particle matter $\left(\mathrm{PM}_{2.5}\right)$ were taken. High concentrations related to high-density traffic, especially during weekdays. EFs were heavily influenced by the pollutant species loads, so the total vehicle traffic and the fraction of HDV. The EF values for HDV were 3.6 and $9.2 \mathrm{~g} \mathrm{~km}^{-1}$, for $\mathrm{CO}$ and $\mathrm{NO}_{\mathrm{x}}$, respectively (5.8 and
\end{abstract}

P. J. Pérez-Martínez (凶) · T. Nogueira · A. Fornaro ·

R. Ynoue - M. F. Andrade

ETSIM-Grupo en Economía Sostenible del Medio Natural (ECSEN), Universidad Politécnica de Madrid, C/Ramiro de Maeztu s/n, 28040 Madrid, Spain

e-mail: pjperez@caminos.upm.es

\section{P. J. Pérez-Martínez}

Institute of Astronomy, Geophysics and Atmospheric Sciences (IAG), Universidad de São Paulo, Rua do Matão, 1226, São

Paulo 05508-090, Brazil

\section{R. M. Miranda}

School of Arts, Science and Humanities, Universidad de São Paulo, Av. Arlindo Bettio, 1000, São Paulo 03828-000, Brazil

M. L. Guardani

São Paulo State Environmental Regulation Agency, São Paulo, Brazil
$0.3 \mathrm{~g} \mathrm{~km}^{-1}$ for LDV). To determine EF estimates, parameters such as velocity of the air, cross-sectional area and length of the tunnel and vehicles passing at 1-h time interval were considered.

Keywords Emission factors - Road traffic $\cdot$ Urban tunnels · São Paulo

\section{Introduction}

The vehicle traffic is the major source of air pollution in megacities. The Metropolitan Region of São Paulo (MRSP) is one of the largest megacities in the world (20 million population in $8,511 \mathrm{~km}^{2}$ ). Most of the population is comprised in an area of $1,000 \mathrm{~km}^{2}$. In the MRSP, there are $\sim 6.5$ million passenger and freight vehicles: $85 \%$ light-duty vehicles (LDVs), $3 \%$ heavy-duty diesel vehicles (HDVs) and $12 \%$ motorcycles. About $55 \%$ of LDVs burn a mixture of $78 \%$ gasoline and $22 \%$ ethanol (gasohol), $4 \%$ use hydrous ethanol (95\% ethanol and $5 \%$ water), $38 \%$ are flex-fuel vehicles that are capable of burning both gasohol and hydrous ethanol, and $2 \%$ use diesel (CETESB 2009). Vehicle traffic is the source of regulated pollutants majority of carbon monoxide $(\mathrm{CO})$, nitrogen oxides $\left(\mathrm{NO}_{\mathrm{x}}\right)$ and hydrocarbons (HC) and contributes to the formation of inhalable particulate matter emissions $\left(\mathrm{PM}_{10}\right.$ and $\left.\mathrm{PM}_{2.5}\right)$ as well as being most source of carbon dioxide $\left(\mathrm{CO}_{2}\right) .97 \%$ of all $\mathrm{CO}$ emissions, $85 \%$ of $\mathrm{HC}, 82 \%$ of $\mathrm{NO}_{\mathrm{x}}, 36 \%$ of sulfur dioxide $\left(\mathrm{SO}_{2}\right)$ and $36 \%$ of all $\mathrm{PM}_{10}$ emissions come from mobile sources (CETESB 2013).

The emission standards for pollutants from road vehicles are regulated in São Paulo by the program for the control of motor vehicle emissions (PROCONVE), established in 1983, which have defined increasingly restrictive standards 
especially for $\mathrm{CO}, \mathrm{NO}_{\mathrm{x}}$ and $\mathrm{PM}_{10}$ emissions (CETESB 2012). Thus, CO emissions of LDVs improved from $24 \mathrm{~g} \mathrm{~km}^{-1}$ in 1989 to $1.3 \mathrm{~g} \mathrm{~km}^{-1}$ in 2013 (L6 phase) and $\mathrm{NO}_{\mathrm{x}}$ emissions of HDVs improved from $14.4 \mathrm{~g} \mathrm{~kW}^{-1}$ in 1994 to $2 \mathrm{~g} \mathrm{~kW}^{-1}$ in 2012 (called P7 phase). The uses of newer technologies in vehicles and fuels (combustion of biodiesel in HDVs) and after-treatment devices have reduced the emissions from road vehicles (Altun and Öner 2013). Three-way catalytic converters have reduced CO, $\mathrm{HC}$ and $\mathrm{NO}_{\mathrm{x}}$ emissions by $90 \%$, and also for diesel HDVs, the use of after-treatment devices has reduced $\mathrm{NO}_{\mathrm{x}}$ and $\mathrm{PM}_{10}$ emissions considerably (Sanchez-Ccoyllo et al. 2009).

Measurements of air pollutants in Brazil are usually taken next to normal road segments or remote places where it is difficult to know the individual contribution of each source. Andrade et al. (2012) showed this point: measurements were taken in open-air urban places and it was difficult to separate vehicle, industrial and other sources. Meteorological parameters-mostly precipitation, wind and humidity — can also influence the final results. Measurements inside road tunnels are taken to eliminate potential noises, allow the identification of individual vehicle sources and can provide information on in-use vehicles to describe actual traffic emissions (SanchezCcoyllo et al. 2009). Tunnel studies assume that the contribution of sources other than the vehicle is negligible (Kristensson et al. 2004; Marr et al. 1999). Road tunnel measurements enable actual emissions for a variety of vehicles to be obtained under certain driving conditions and environment and provide information that complements dynamometer test results. Although it is possible to estimate emission factors (EFs) under real urban conditions inside tunnels, the accuracy of the calculations depends on the dispersion of the pollutants (Belalcazar et al. 2010). Another important consideration is that the rate of occurrence of photochemical processes is small since there is no action of radiation. In order to implement public policies concerning air quality and public health, there is a need to develop accurate emission inventories and road traffic EFs, which are one of the main sources of uncertainties; it is necessary to reduce these uncertainties, together with the precision and accuracy of the geographical and the meteorological input data, to manage air quality more efficiently from the transport policy perspective (Molina and Molina 2004; Huerta et al. 2012).

Emissions from road vehicles are important to evaluate the contribution of road traffic to energy demand (Alam et al. 2013) and environmental pollution (Colberg et al. 2005a) in urban areas. EFs describe the emitted mass (g) of a compound per distance $(\mathrm{km})$ or volume of fuel consumed and express the individual contribution of each pollutant (Colberg et al. 2005b). The present study shows the results of $\mathrm{PM}_{2.5}, \mathrm{CO}, \mathrm{CO}_{2}$ and $\mathrm{NO}_{\mathrm{x}}$ emission factors estimated in two road tunnels in the MRSP, Brazil. The MRSP can be considered a good example of using biofuels in large scale. The vehicles run with gasohol (gasoline with 22-25\% ethanol) and pure ethanol for LDV fleet, and diesel or biodiesel for HDV fleet. The results are representative of Brazilian conditions and in particular for a mixed fleet (bypass tunnel) and for a LDV fleet of vehicles (urban tunnel). We study the effects that different fleet composition, traffic density and vehicle-related pollutant loading have on the measured EFs. In the Jânio Quadros tunnel (TJQ), only LDVs are allowed, so it is possible to evaluate this source and know its contribution. Inside the Rodoanel tunnel (TRA), some of the vehicles are HDVs, providing data to know the contribution of diesel vehicles. The results are also compared with reviewed emission factors for $\mathrm{CO}$ and $\mathrm{NO}_{\mathrm{x}}$ and with emission factors in currently used emission inventories and dynamometer studies in São Paulo. The results presented in this study suggest that $\mathrm{CO}$ and $\mathrm{NO}_{\mathrm{x}}$ emissions from LDVs are underestimated compared to the Brazilian and European emissions standards for LDVs, oppositely to the EFs of HDVs. The implications of these underestimation and overestimation of $\mathrm{CO}$ and $\mathrm{NO}_{\mathrm{x}}$ emissions are discussed. The analysis presented here complemented and discussed previous results on emission factor based on tunnel measurements in São Paulo for measurements performed in 2004 (Sanchez-Ccoyllo et al. 2009; Martins et al. 2006).

\section{Materials and methods}

Location, traffic volume and sampling analysis

Field measurements were taken in two experimental campaigns in TJQ, from May 2 to 13, 2011, and in TRA, from July 4 to 19,2011 . TJQ is located in the southwest area of São Paulo. It is a two-lane tunnel, $850 \mathrm{~m}$ length, and the speed limit is $70 \mathrm{~km} \mathrm{~h}^{-1}$. Emissions are coming from gasohol- and ethanol-powered vehicles. TRA tunnel is located in the northeast area of São Paulo. It is a two-lane tunnel, $1,150 \mathrm{~m}$ length, and the speed limit is $90 \mathrm{~km} \mathrm{~h}^{-1}$ (LDVs) and $70 \mathrm{~km} \mathrm{~h}^{-1}$ (HDVs). LDVs and HDVs burning gasohol, ethanol and diesel use TRA. Pollutant air concentrations were measured at the midpoint inside the tunnels (Fig. 1), and background air concentrations were measured outside the tunnels. The sites outside the tunnels were located far from the tunnels in order to avoid their influence. Table 1 summarizes the assets of the two tunnels-length $(l)$, cross-sectional area $(s)$, perimeter $(P)$, natural flow velocity $\left(u_{0}\right)$, inlet and outlet ventilation rates $\left(a_{\mathrm{i}}, a_{\mathrm{o}}\right)$ and carbon monoxide (CO) concentrations in inlet and outlet air $\left(C_{\mathrm{i}}, C_{\mathrm{o}}\right)$-and the input data for computations 


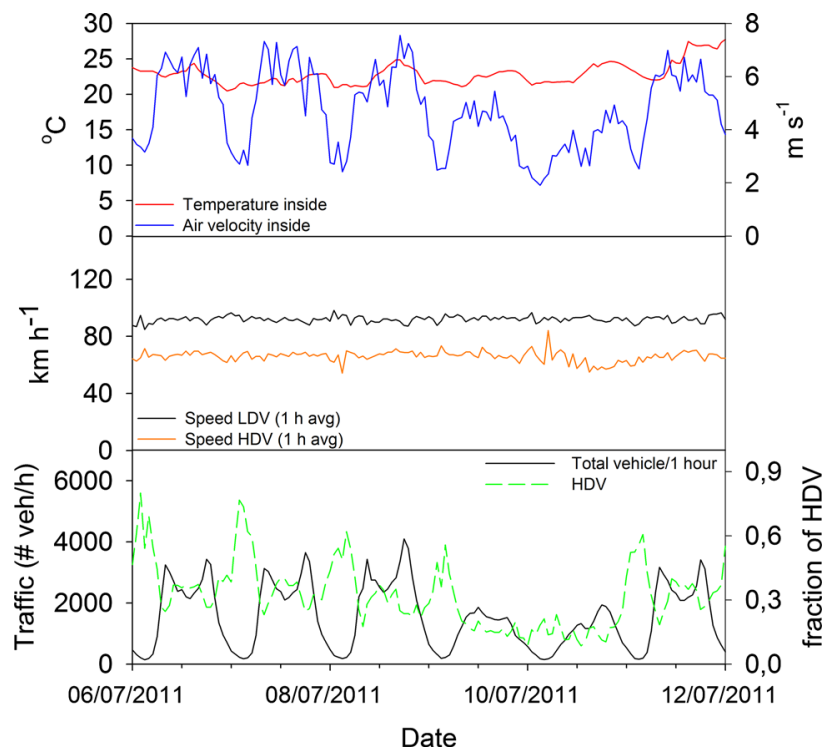

Fig. 1 Temperature, air speed, vehicle speed, traffic density and vehicle fleet composition, discrimination between LDV and HDV, during the measurements in the Rodoanel tunnel (TRA)

Table 1 Estimation conditions for tunnels (one-way, 2 lanes per direction)

\begin{tabular}{|c|c|c|}
\hline & $\begin{array}{l}\text { TRA } \\
\text { (normal/ } \\
\text { congestion) }\end{array}$ & $\begin{array}{l}\text { TJQ } \\
\text { (normal/ } \\
\text { congestion) }\end{array}$ \\
\hline Length, $l(\mathrm{~m})$ & 1.150 & 850 \\
\hline Cross-sectional area, $s\left(\mathrm{~m}^{2}\right)$ & 100.5 & 80.6 \\
\hline Perimeter, $P(\mathrm{~m})$ & 50.3 & 45.1 \\
\hline Natural flow velocity, $u_{0}\left(\mathrm{~m} \mathrm{~s}^{-1}\right)$ & $4.9 / 1.0$ & $6.1 / 1.0$ \\
\hline Inlet ventilation rate, $a_{\mathrm{i}}\left(\mathrm{min}^{-1}\right)$ & $0.3 / 0.2$ & $0.3 / 0.2$ \\
\hline Outlet ventilation rate, $a_{\mathrm{o}}\left(\mathrm{min}^{-1}\right)$ & $0.3 / 0.2$ & $0.3 / 0.2$ \\
\hline $\begin{array}{l}\text { Concentration in inlet air, } C_{\mathrm{i}} \text { ( } \mu \mathrm{g} \mathrm{CO} \\
\mathrm{m}^{-3} \text { ) }\end{array}$ & $2.5 / 5.0$ & $2.5 / 5.0$ \\
\hline $\begin{array}{l}\text { Concentration in outlet air, } C_{\mathrm{o}}(\mu \mathrm{g} \mathrm{CO} \\
\left.\mathrm{m}^{-3}\right)\end{array}$ & $3.9 / 7.6$ & $3.9 / 7.6$ \\
\hline Traffic volume, $V$ (\#vehicles $\mathrm{h}^{-1}$ ) & $\begin{array}{l}3,000 / \\
1,600\end{array}$ & $\begin{array}{r}2,000 / \\
1,500\end{array}$ \\
\hline Vehicle speed, $v\left(\mathrm{~km} \mathrm{~h}^{-1}\right)$ & $83 / 12$ & $72 / 10$ \\
\hline Percentage $\mathrm{HDV}, f_{\mathrm{D}}$ (no units) & $0.3 / 0.0$ & $0.0 / 0.0$ \\
\hline Vehicle emission factor $\left(\mathrm{g} \mathrm{NO}_{\mathrm{x}} \mathrm{kg}^{-1}\right)$ & $12 / 48$ & $8 / 32$ \\
\hline
\end{tabular}

of pollutant concentrations and emission factors-traffic volume $(\mathrm{V})$, vehicle speed (v) and percentage of HDVs $\left(f_{D}\right)$. Transverse ventilation was used in the two tunnels. Table 1 also presents two cases of normal and congested traffic with mean vehicular speeds of $83 / 12$ (TRA) and $72 / 10 \mathrm{~km} \mathrm{~h}^{-1}$ (TJQ). Based on measurements, natural airflow velocities are considered to be 4.9 and $1.0 \mathrm{~m} \mathrm{~s}^{-1}$ for normal and congested traffic conditions in TRA and $6.1-1.0 \mathrm{~m} \mathrm{~s}^{-1}$ in TJQ. Inlet and outlet ventilation rates-
$0.3 \mathrm{~min}^{-1}$ for the normal and $0.2 / \mathrm{min}$ for the congested traffic conditions-and $\mathrm{CO}$ inlet and outlet concentrations $-2.5-3.9 \mu \mathrm{g} \mathrm{CO} \mathrm{m}{ }^{3}$ for the normal and 5.0-7.6 $\mu \mathrm{g}$ $\mathrm{CO} \mathrm{m}^{3}$ for the congested traffic conditions-are chosen based on maximum rates for other road tunnels (Chang and Rudy 1990).

Cameras were installed in TJQ to obtain the traffic volumes (3,000 vehicles $\mathrm{h}^{-1}$ for normal and 1,600 in congested traffic conditions). In TRA, an automatic traffic count system-induction loops combined with vehicle speed classification-provided information of vehicle counts $\left(2,000-1,500\right.$ vehicles $\left.\mathrm{h}^{-1}\right)$, type (LDVs with lengths $<6 \mathrm{~m}$ and HDVs with lengths $>6 \mathrm{~m}$ ) and average vehicle speed classification every $15 \mathrm{~min}$. In TJQ, traffic counts were performed with optical counter and vehicles were classified as motorcycles, light passenger vehicles, light-duty trucks/vans and taxis, whereas those using the TRA tunnel were classified as LDVs $(70 \%)$ and HDVs $(30 \%)$. Inside and outside the tunnels, air measurements were taken simultaneously to determine the concentrations of the species: Particulate matter lower than $10 \mu \mathrm{g}\left(\mathrm{PM}_{10}\right)$, nitrogen oxide species $\left(\mathrm{NO}_{\mathrm{x}}\right), \mathrm{CO}$ and carbon dioxide $\left(\mathrm{CO}_{2}\right)$. It is noted that concentration measurements outside and inside the tunnels will depend upon the meteorological conditions and the monitoring location. The monitoring was performed continuously by the São Paulo State Environmental Protection Agency (CETESB 2009). The pollutants measured, analyzers and methods are summarized in Table 2.

Outside and inside tunnel measurements of fine PM (with an aerodynamic diameter $<2.5 \mu \mathrm{g}, \mathrm{PM}_{2.5}$ ) and coarse PM (with an aerodynamic diameter between 2.5 and $10 \mu \mathrm{g}$, $\mathrm{PM}_{2.5-10}$ ) were recorded simultaneously using air samplers (Partisol $^{\mathrm{TM}}$ Dichotomous Ambient Particulate Sampler). These samplers operated at a rate of $16.71 \mathrm{~min}^{-1}$. Six-hour samplings (2-3 per day) were performed. Flow rates were calibrated in the laboratory and checked before and after each filter change. Mass concentrations were obtained gravimetrically using an electronic microbalance with a sensitivity of $1 \mu \mathrm{g}$ (the filters were weighted before and after sampling on the microbalance after calibration at constant temperature and humidity). The mass concentration measurements of $\mathrm{PM}_{10}$ were also taken by beta-gauges (5014i-Beta). Measurements of the $\mathrm{NO}_{\mathrm{x}}, \mathrm{CO}$ and $\mathrm{CO}_{2}$ at both tunnels were carried out with $\mathrm{NO}_{\mathrm{x}}$ (Thermo electron 42i-HL), $\mathrm{CO}$ (Thermo electron 48B) and $\mathrm{CO}_{2}$ (LICOR6262 and Picarro-G1301) analyzers applying the chemiluminescence, photometry and infrared methodologies, respectively. Because these analyzers were double implemented, inside and outside the tunnels, they were checked in several quality comparison measurements in the laboratory before and after the field campaigns. The calibration of the automatic samplers was executed everyday at a 
Table $2 \mathrm{CO}_{2}$ and pollutants measured in the Janio Quadros (TJQ) and Rodoanel (TRA) tunnels and methods

\begin{tabular}{|c|c|c|c|c|c|}
\hline Pollutant & $\mathrm{PM}_{2.5}-\mathrm{PM}_{2.5-10}$ & $\mathrm{PM}_{10}$ & $\mathrm{NO}_{\mathrm{x}}$ & $\mathrm{CO}$ & $\mathrm{CO}_{2}$ \\
\hline Method & Gravimetry & Beta radiation & Chemiluminescence & Non-dispersive infrared photometry & Infrared analysis \\
\hline Analyzer & Partisol 2000-D & 5014i-Beta & Thermo electron (42i-HL) & Thermo electron (48B) & $\begin{array}{l}\text { LICOR-6262 } \\
\text { Picarro-G1301 }\end{array}$ \\
\hline Accuracy & $\pm 2.1-0.8 \%^{\mathrm{a}}$ & $\pm 5 \%$ & $\pm 1.5 \%$ & $\pm 1-2.5 \%$ & $\pm 1 \%$ \\
\hline Resolution & $6 \mathrm{~h}$ & $1 \mathrm{~min}$ & $5 \mathrm{~min}$ & $5 \mathrm{~min}$ & $1 \mathrm{~min}$ \\
\hline Units & $\mu \mathrm{g} \mathrm{m}^{-3}$ & $\mu \mathrm{g} \mathrm{m}^{-3}$ & $\mathrm{ppb}$ & ppm mg ${ }^{-1} \mathrm{~m}^{-3}$ & ppm \\
\hline
\end{tabular}

a The drift in the flow rates did not exceed these values

specific hour, and the corrected factors were found to be $<5 \%$. All the measurements were aggregated to $1-\mathrm{h}$ averages for further evaluation of the emission factors.

\section{Emission factors}

To calculate the emission factors, we used the following expression (Marr et al. 1999):

$E_{\mathrm{p}}=10^{3}\left(\frac{\Delta[\mathrm{P}]}{\Delta\left[\mathrm{CO}_{2}\right]+\Delta[\mathrm{CO}]}\right) \omega_{\mathrm{c}}$

where $E_{\mathrm{p}}$ is the emission factor of pollutant $\mathrm{P}\left(\mathrm{PM}_{10}\right.$, $\mathrm{PM}_{2.5}, \mathrm{PM}_{2.5-10}$ and $\mathrm{NO}_{\mathrm{x}}$, in $\mathrm{g}$ per $\mathrm{kg}$ of fuel burned), $\Delta[\mathrm{P}]$ is the concentration of the pollutant (subtracted from the background value measured outside the tunnel, in $\mu \mathrm{g} \mathrm{m}^{-3}$ ), and $\Delta\left[\mathrm{CO}_{2}\right]$ and $\Delta[\mathrm{CO}]$ are $\mathrm{CO}_{2}$ and $\mathrm{CO}$ concentrations. The conversions of $\mathrm{CO}_{2}$ and $\mathrm{CO}$ to mass units were done using a molecular weight of $12 \mathrm{~g} \mathrm{~mol}^{-1}$, rather than $44 \mathrm{~g} \mathrm{~mol}^{-1}$ and $28 \mathrm{~g} \mathrm{~mol}^{-1}$, and the concentrations were expressed in $\mu \mathrm{g} \mathrm{C} \mathrm{m}{ }^{-3}$. The weight fractions of fuel carbon $\omega_{\mathrm{c}}$ were $0.85-0.87 \mathrm{~g}$ of carbon per gram of fuel, for gasohol and diesel, respectively. The expression 1 can be used directly in TJQ since the tunnel has mainly LDVs. In the TRA, emissions from HDVs were obtained discounting the contribution of LDVs to the total emissions. Tunnel studies have shown that emissions from LDVs and HDVs have similar CO emission rates per kilometer (Kirchstetter et al. 1999, 2002; McGaughey et al. 2004). $\mathrm{CO}_{2}$ emissions were calculated from traffic data and fuel consumption parameters using the following equation:

$\frac{\Delta\left[\mathrm{CO}_{2}\right]_{\mathrm{D}}}{\Delta\left[\mathrm{CO}_{2}\right]}=\frac{f_{\mathrm{D}} U_{\mathrm{D}} \rho_{\mathrm{D}} \omega_{\mathrm{D}}}{\left(f_{\mathrm{D}} U_{\mathrm{D}} \rho_{\mathrm{D}} \omega_{\mathrm{D}}\right)+\left(\left(1-f_{\mathrm{D}}\right) \cdot U_{\mathrm{G}} \rho_{\mathrm{G}} \omega_{\mathrm{G}}\right)}$

where $\Delta\left[\mathrm{CO}_{2}\right]_{\mathrm{D}}$ is the component of $\Delta\left[\mathrm{CO}_{2}\right]$ emissions resulting from the diesel burned, $f_{\mathrm{D}}$ is the percentage of $\mathrm{HDV}, U$ is the average fuel consumption rate $(75$ and $450 \mathrm{~g} \mathrm{~km}^{-1}$ for gasohol and diesel fuel, respectively), $\rho$ is the fuel density (785 and $850 \mathrm{~g} \mathrm{l}^{-1}$ for gasohol and diesel fuel, respectively), $\omega$ is the fuel carbon fraction $(0.85 \mathrm{~g}$ of $\mathrm{C}$ per $\mathrm{g}$ of fuel and 0.87 for gasohol and diesel, respectively). The subscripts $\mathrm{D}$ and $\mathrm{G}$ denote diesel and gasohol. The share of HDV was expressed by:

$\Delta[P]_{\mathrm{HDV}}=\Delta[P]-\Delta[\mathrm{CO}]\left(1-f_{D}\right)\left(\frac{\Delta[P]_{\mathrm{LDV}}}{\Delta[\mathrm{CO}]_{\mathrm{LDV}}}\right)$

where $\Delta[P]_{\mathrm{HDV}}$ is the component of $\Delta[P]$ in TRA related to $\mathrm{HDV}$ emissions, and $\Delta[\mathrm{CO}] \cdots\left(1-f_{\mathrm{D}}\right)$ is the fraction of $\Delta[\mathrm{CO}]$ emissions from LDV. The emission rates for LDV, $\Delta[P]_{\mathrm{LDV}} / \Delta[\mathrm{CO}]_{\mathrm{LDV}}$, were measured in TJQ. These ratios were 0.025 and 0.054 for $\mathrm{PM}_{10}$ and $\mathrm{NO}_{\mathrm{x}}$, respectively. Finally, the emission factor of pollutant $\mathrm{P}$ and vehicle type $\mathrm{i}$ (LDV and HDV), $E_{\mathrm{P}, \mathrm{i}}^{*}$ (expressed in grams of pollutant per driven kilometer, $\mathrm{g} \mathrm{km}^{-1}$ ), was obtained using the following expression:

$E_{\mathrm{P}, \mathrm{i}}^{*}=E_{\mathrm{P}, \mathrm{i}} \cdot U_{\mathrm{i}}$

where $U_{\mathrm{i}}$ is the fuel consumption of vehicle i (LDVs and HDVs), and $\mathrm{E}_{\mathrm{P}, \mathrm{i}}$ comes from Eq. 1. In Eq. 4, $U_{\mathrm{i}}$ depends on the $\mathrm{CO}_{2}$ emission factor $\left(E_{\mathrm{CO} 2}\right.$ in grams of $\mathrm{CO}_{2}$ equivalent per driven kilometer, $\left.\mathrm{gCO}_{2} \mathrm{~km}^{-1}\right)$, the density of fuel $\mathrm{j}\left(\rho_{\mathrm{j}}\right.$, gasohol for LDV, $785 \mathrm{~g} \mathrm{l}^{-1}$ of fuel, and diesel for HDV, $850 \mathrm{~g} \mathrm{l}^{-1}$ of fuel) and the carbon intensity of fuel $\mathrm{j}\left(c_{\mathrm{j}}\right.$, $2,331 \mathrm{~g}$ of $\mathrm{CO}_{2} \mathrm{l}^{-1}$ of gasohol and 2,772 $\mathrm{g}$ of $\mathrm{CO}_{2} \mathrm{1}^{-1}$ of diesel). Therefore, $U_{\mathrm{i}}$ can be calculated according to expression 5:

$U_{\mathrm{i}}=E_{\mathrm{CO}_{2}, \mathrm{i}} \frac{\rho_{\mathrm{j}}}{c_{\mathrm{j}}}$

$\mathrm{E}_{\mathrm{CO} 2}$ depends on the characteristics of the tunnel (Table 1) and the total traffic flow per time unit. $\mathrm{E}_{\mathrm{CO} 2}$ for LDV and HDV were obtained using the following expressions:

$E_{\mathrm{CO}_{2}, \mathrm{LDV}}=10^{-6} \frac{\Delta\left[\mathrm{CO}_{2}\right]_{\mathrm{LDV}} \cdot s \cdot u_{0} \cdot t}{V \cdot\left(1-f_{\mathrm{D}}\right) \cdot l}$

$E_{\mathrm{CO}_{2}, \mathrm{HDV}}=10^{-6} \frac{\Delta\left[\mathrm{CO}_{2}\right]_{\mathrm{HDV}} \cdot s \cdot u_{0} \cdot t}{V \cdot f_{\mathrm{D}} \cdot l}$

where $\Delta\left[\mathrm{CO}_{2}\right]$ is the difference between the concentrations inside and outside of the tunnel of $\mathrm{CO}_{2}\left(\mu \mathrm{g} \mathrm{m}^{-3}\right), s$ is the cross-sectional area of the tunnel $\left(\mathrm{m}^{2}\right), u_{0}$ is the velocity of 
Table 3 Summary table including parameters used in Eqs. 1-7

\begin{tabular}{lllllll}
\hline & $\begin{array}{l}\Delta\left[\mathrm{PM}_{10}\right]_{\mathrm{LDV}} / \Delta[\mathrm{CO}]_{\mathrm{LDV}} \\
\text { (no units) }\end{array}$ & $\begin{array}{l}\Delta\left[\mathrm{NO}_{\mathrm{x}}\right]_{\mathrm{LDV}} / \Delta[\mathrm{CO}]_{\mathrm{LDV}} \\
\text { (no units) }\end{array}$ & $U_{\mathrm{G}, \mathrm{D}}\left(\mathrm{g} \mathrm{km}^{-1}\right)$ & $\rho_{\mathrm{G}, \mathrm{D}}\left(\mathrm{g} \mathrm{l}^{-1}\right)$ & $\omega_{\mathrm{G}, \mathrm{D}}\left(\mathrm{gC} \mathrm{g}^{-1}\right)$ & $c_{\mathrm{G}, \mathrm{D}}\left(\mathrm{gCO}_{2} 1^{-1}\right)$ \\
\hline $\mathrm{LDV}(\mathrm{g})$ & 0.025 & 0.054 & 75 & 785 & 0.85 & 2,331 \\
$\mathrm{HDV}(\mathrm{d})$ & n.d. & n.d. & 450 & 850 & 0.87 & 2,772 \\
\hline
\end{tabular}

the air wind measured inside the tunnel $\left(\mathrm{m} \mathrm{s}^{-1}\right), t$ is the time interval corresponding to $1 \mathrm{~h}(3,600 \mathrm{~s}), V$ is the number of vehicles passing the tunnel at the time $t, f_{\mathrm{D}}$ is the percentage of HDV, and $l$ is the tunnel length $(\mathrm{km})$. Finally, the parameters used in the estimation of the emission factors are summarized in Table 3.

\section{Results and discussion}

Hourly average concentrations are measured together with the number of vehicles inside and outside of the two tunnels. Figure 2 shows the temporal evolutions, with a time resolution of $1 \mathrm{~h}$, of $\mathrm{NO}, \mathrm{NO}_{\mathrm{x}}, \mathrm{NO}_{2}, \mathrm{CO}, \mathrm{CO}_{2}, \mathrm{VOCs}, \mathrm{CH}_{4}, \mathrm{PM}_{10}$ and traffic for the second week of sampling in TRA. PM ${ }_{10}$ is correlated with vehicle traffic, especially at peak hours (in the morning 06:00-09:00 and afternoon 16:00-19:00). In TRA, vehicle density was high during these hours at $\approx 2,560 \pm 688$ vehicles per hour. $\mathrm{PM}_{10}$ concentrations inside the two tunnels during the peak hours on working days were $245 \pm 59 \mathrm{\mu g} \mathrm{m}^{-3}$ and $123 \pm 31 \mu \mathrm{g} \mathrm{m}^{-3}$ for TRA and TJQ, respectively. In TRA on weekends, the highest concentration, corresponding the hour with the highest vehicle density, was $119 \pm 24 \mathrm{~g} \mathrm{~m}^{-3}$ for a vehicle density of $1,636 \pm 170$ per hour. For the night periods on working days (0:00-5:00), the average concentration was $110 \pm 19 \mu \mathrm{g} \mathrm{m}^{-3}$, indicating that even at low vehicle density, the concentration of primary emissions of $\mathrm{PM}_{10}$ was quite significant due to the HDVs traffic.

$\mathrm{NO}_{\mathrm{x}}$ concentrations were evaluated in both tunnels. $\mathrm{NO}_{\mathrm{x}}$ emission shows higher concentrations in TRA compared with TJQ. The marked difference between the two tunnels indicates the significant emissions of $\mathrm{NO}_{\mathrm{x}}$ by HDVs. Diesel vehicles are an important source of $\mathrm{NO}_{\mathrm{x}}$, and on average, concentration values in TRA were about ten times greater than in TJQ. In TRA, $\mathrm{NO}_{\mathrm{x}}$ was mainly presented as NO (Fig. 2), with and $\mathrm{NO}_{2} / \mathrm{NO}_{\mathrm{x}}$ ratio inside the tunnel of $1.9 \pm 0.4 \%$ during working days $(35.7 \pm 21.1 \%$ at the background site) and $2.3 \pm 0.3 \%$ on weekends $(35.9 \pm 15.5 \%)$. The difference between inside and outside tunnel concentrations was explained by the higher ambient contribution with the $\mathrm{NO}_{2}$ concentration at the background site. Consequently, the higher ratio observed during weekends was due to the higher relative contribution of the ambient $\mathrm{NO}_{2}$ to the overall concentration.

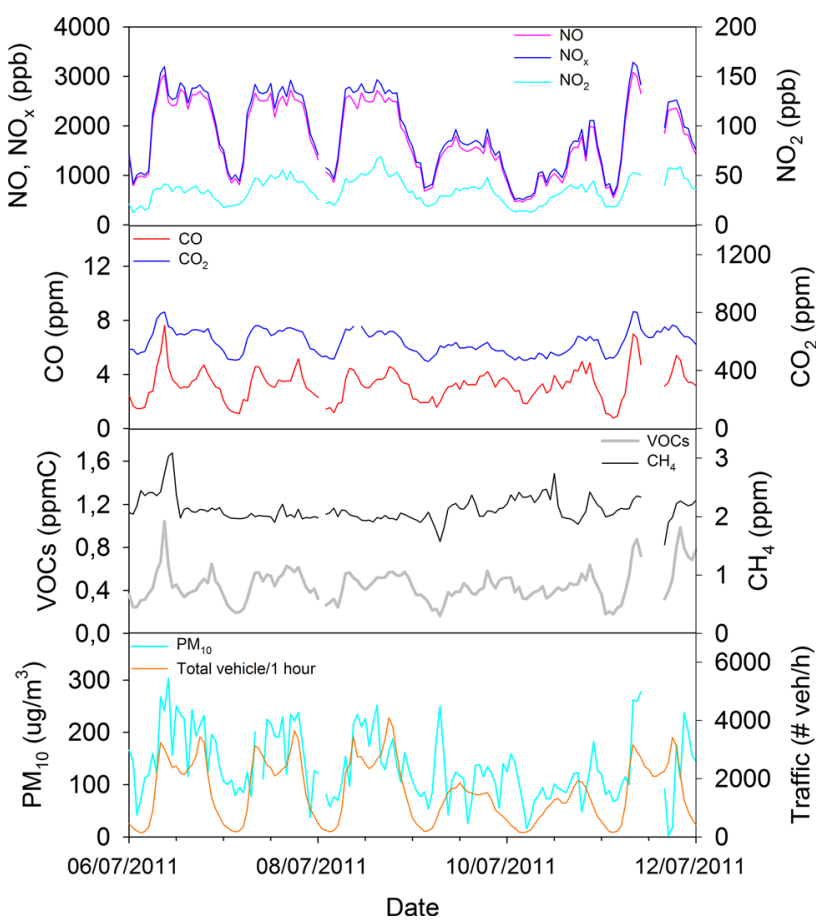

Fig. 2 Time variations of the researched gas and particulate-associated compounds inside the Rodoanel tunnel (TRA)

Important relationship between $\mathrm{CO}$ emissions and number of vehicles was found in the two tunnels. CO concentrations inside the two tunnels during the peak hours on working days were $6.3 \pm 1.5 \mathrm{ppm}$ and $6.7 \pm 1.8 \mathrm{ppm}$ for TRA and TJQ, respectively. At the investigated period, evening peak was observed in TJQ due to traffic congestion. In TRA on weekends, the highest concentration was $4.4 \pm 0.7 \mathrm{ppm}$ for a vehicle density of $2,712 \pm 161$ per hour (Fig. 2). For the night periods on working days (0:00-5:00), the average concentration was $2.0 \pm 1.0 \mathrm{ppm}$, indicating that even at low vehicle density, the concentration of primary emissions of $\mathrm{CO}$ was quite significant. A significant reduction of $\mathrm{CO}$ emissions from LDVs was observed in TJQ compared with former studies (Martins et al. 2006). Reductions of CO emissions can be explained by the improved combustion of gasoline and ethanol use. Ethanol has higher oxygen content resulting in lower particle and CO emissions (Correa and Arbilla 2008). All pollutants showed higher concentration values inside the tunnel than outside, expressed as ratios. In TJQ, these ratios 

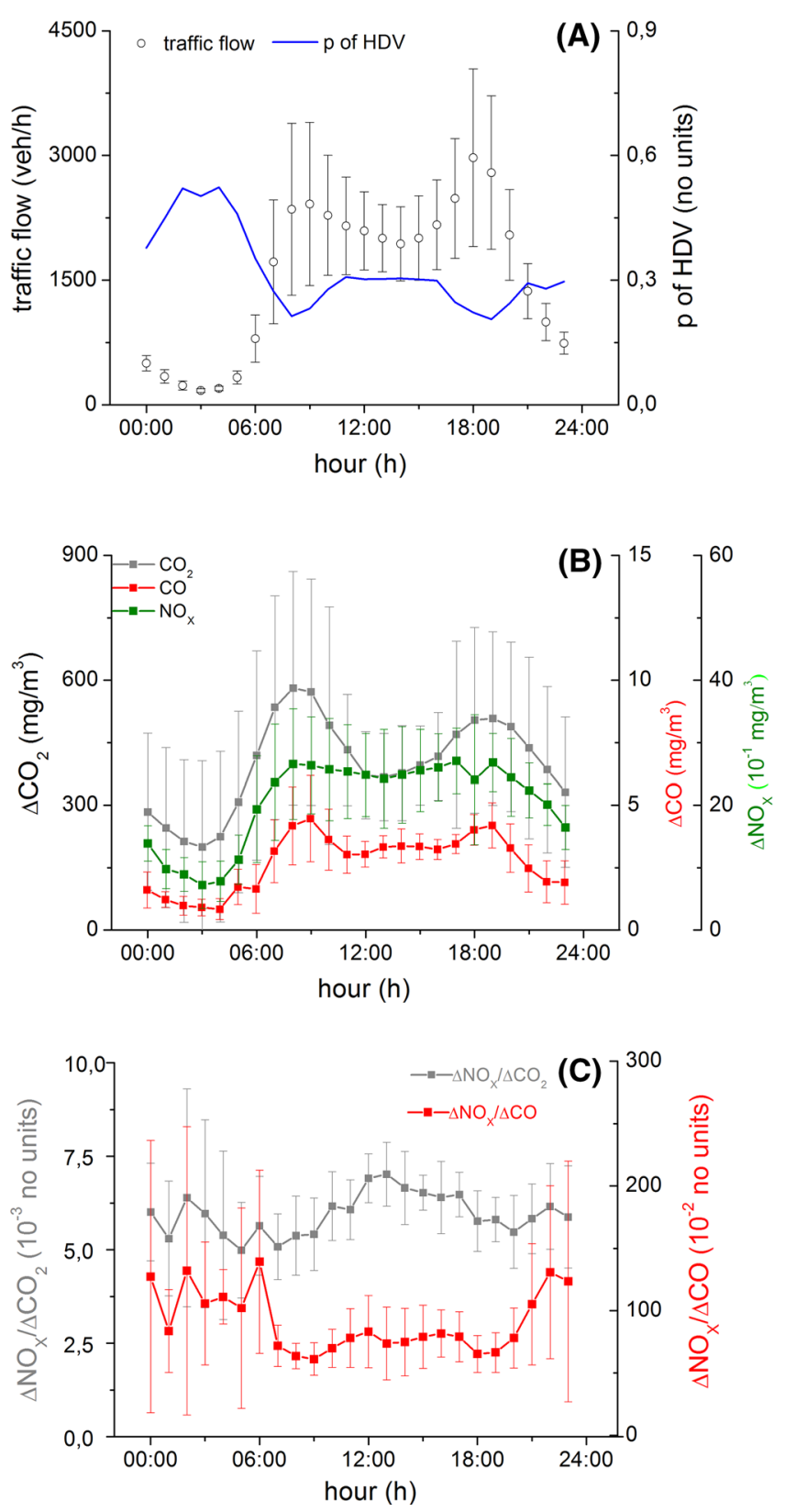

Fig. 3 Traffic counts, pollutant concentrations and $\mathrm{NO}_{\mathrm{x}}$ to $\mathrm{CO}$ and $\mathrm{CO}_{2}$ ratios. One-hour averages from 00:00 to 23:00, average over the fourteen sampling days in the Rodoanel (TRA) and Janio Quadros (TJQ) tunnels. Average diurnal traffic flow (vehicles $\mathrm{h}^{-1}$ ) and fraction of the flow, which was classified as heavy-duty diesel during

were: $3.3,1.6$ and 7.1 for $\mathrm{CO}, \mathrm{NO}_{\mathrm{x}}$, and $\mathrm{PM}_{10}$, respectively. In TRA, the differences between concentrations were $3.1,9.0$ and 2.2 .

Background-corrected concentrations, ratios and traffic counts

The background-corrected $\mathrm{CO}, \mathrm{CO}_{2}, \mathrm{NO}_{\mathrm{x}}$ concentrations, $\mathrm{NO}_{\mathrm{x}}$ to $\mathrm{CO}$ and $\mathrm{CO}_{2}$ ratios $\left(\Delta\left[\mathrm{NO}_{\mathrm{x}}\right] / \Delta[\mathrm{CO}], \Delta\left[\mathrm{NO}_{\mathrm{x}}\right] /\right.$
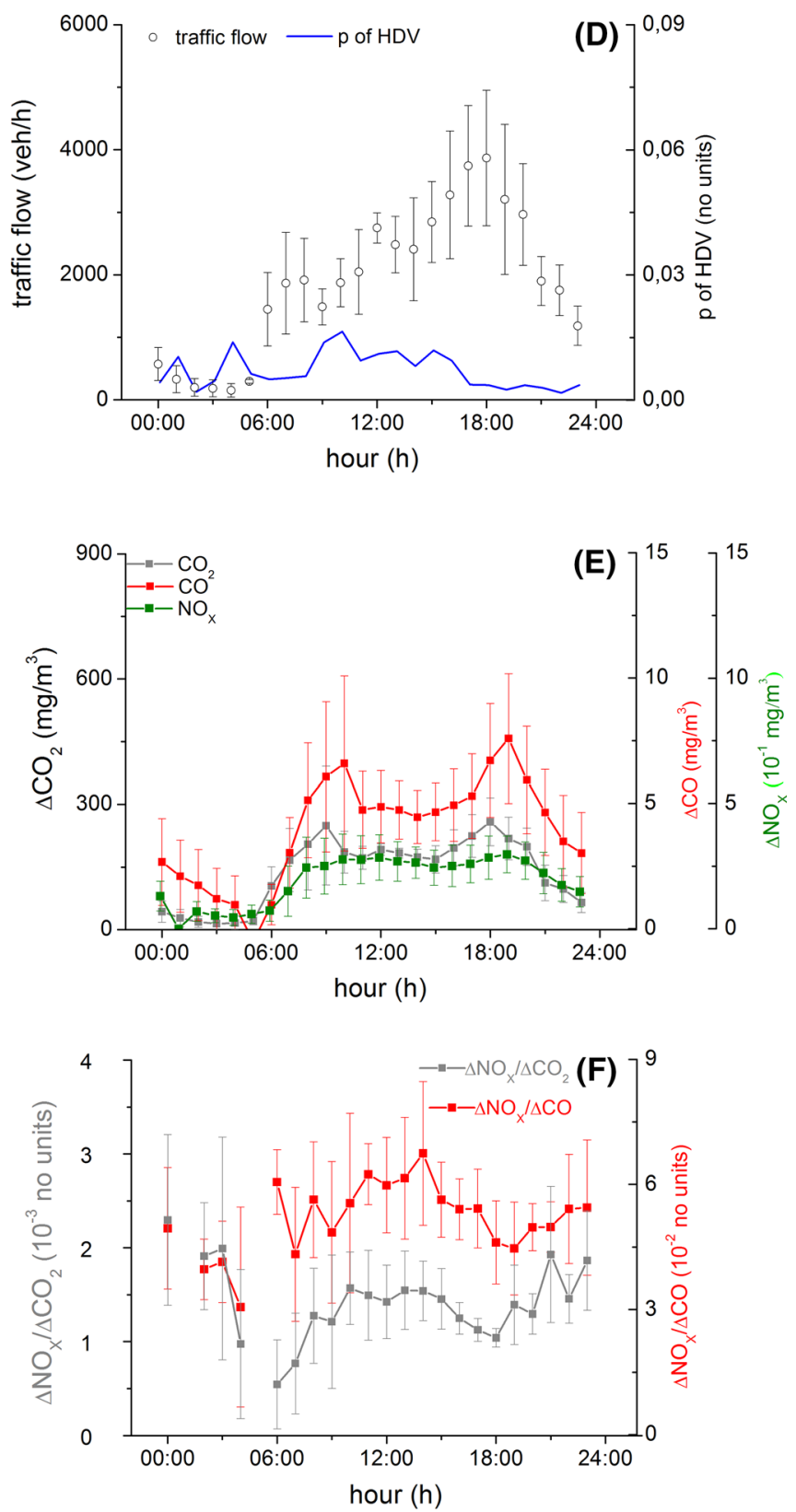

the 14 days of the study, HDVs based on vehicle counts (a, d). Pollutant concentrations (exit-inside the tunnel) of $\mathrm{CO}_{2}, \mathrm{CO}$ and $\mathrm{NO}_{\mathrm{x}}$ (b, e). Ratios of $\Delta\left[\mathrm{NO}_{\mathrm{x}}\right]$ to $\Delta\left[\mathrm{CO}_{2}\right]$ and $\Delta[\mathrm{CO}](\mathrm{c}, \mathrm{f})$. Note error bars denote the standard deviation of the mean

$\left.\Delta\left[\mathrm{CO}_{2}\right]\right)$, and $\mathrm{PM}_{10}$ to $\mathrm{CO}_{2}$ ratios $\left(\Delta\left[\mathrm{PM}_{10}\right] / \Delta\left[\mathrm{CO}_{2}\right]\right)$ measured during these two tunnel experiments are shown in Figs. 3b, c, e, f and 4a-d. Together with the concentrations and ratios, Fig. 3a, d shows the traffic counts and percentage of HDVs. In TRA, it can be seen that $\mathrm{CO}_{2}, \mathrm{CO}$ and $\mathrm{NO}_{\mathrm{x}}$ concentrations increase during the morning peak hour (8:00-9:00 a.m.) due to increased LDV traffic volumes (Fig. 3a). Figure $3 b$ also shows that $\mathrm{NO}_{x}$ and $\mathrm{CO}_{2}$ increase by similar relative amounts but $\mathrm{CO}$ increases at a 

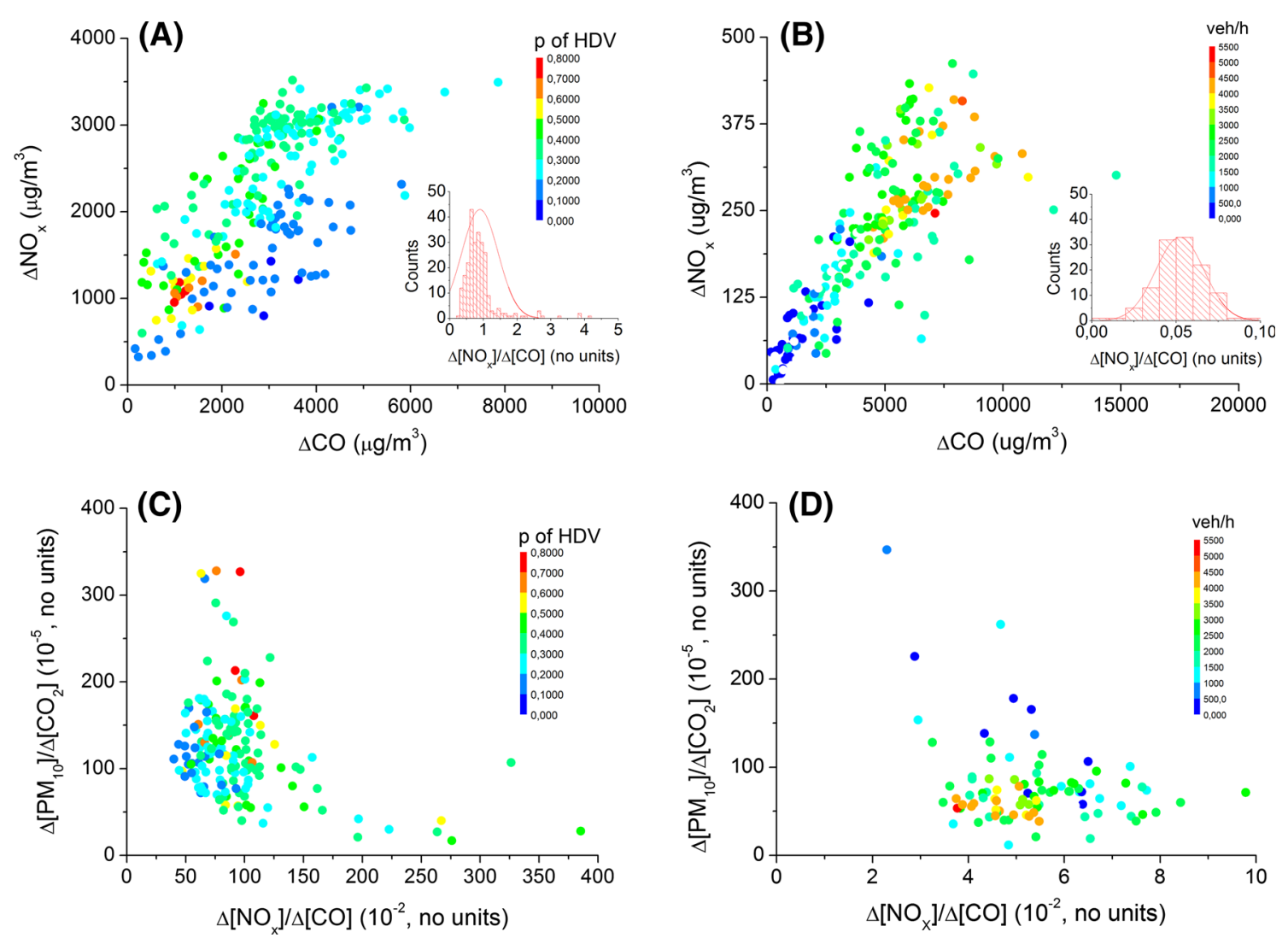

Fig. $4 \mathrm{NO}_{\mathrm{x}}$ and $\mathrm{PM}_{10} / \mathrm{CO}_{2}$ versus $\mathrm{CO}(\mathbf{a}, \mathbf{b})$ and $\mathrm{NO}_{\mathrm{x}} / \mathrm{CO}$ background-corrected concentrations (c, $\mathbf{d})$. The color scale map indicates the percentage of HDV in TRA (a, c) and the total traffic per hour in

TJQ (b, d). The concentrations outside the two tunnels were used as background concentrations and they were subtracted to the values inside

higher rate (proportional to $\mathrm{CO}$ emissions factor of LDVs). Thus, $\Delta\left[\mathrm{NO}_{\mathrm{x}}\right] / \Delta\left[\mathrm{CO}_{2}\right]$ does not show any trend over the morning peak hour, whereas $\Delta\left[\mathrm{NO}_{\mathrm{x}}\right] / \Delta[\mathrm{CO}]$ decreases for the same period (Fig. 3c). Generally, as the morning progresses, vehicle speeds increase due to increased LDV and decreased HDV traffic. This difference demonstrates the advantage of using $\Delta\left[\mathrm{NO}_{\mathrm{x}}\right] / \Delta\left[\mathrm{CO}_{2}\right]$ rather than $\Delta\left[\mathrm{NO}_{\mathrm{x}}\right] /$ $\Delta[\mathrm{CO}]$ ratios as the basis for tracking LDV and HDV emissions, especially where fleet composition is changing from low-diesel HDV traffic to high-gasoline LDV traffic. Generally, in TJQ, it can be seen that $\mathrm{CO}_{2}$ and $\mathrm{CO}$ concentrations increase during the afternoon peak hour due to the increased LDV traffic and decreased speeds (Fig. 3d). Figure $3 \mathrm{e}$ also shows that $\mathrm{CO}_{2}$ concentrations increase by a higher rate than $\mathrm{NO}_{\mathrm{x}}$, and $\Delta\left[\mathrm{NO}_{\mathrm{x}}\right] / \Delta\left[\mathrm{CO}_{2}\right]$ ratio shows a significant trend over the afternoon (Fig. $3 \mathrm{f}$ ). The existence of a trend in $\Delta\left[\mathrm{NO}_{\mathrm{x}}\right] / \Delta\left[\mathrm{CO}_{2}\right]$, proportional to $\mathrm{NO}_{\mathrm{x}} \mathrm{LDV}$ emission factors, in Fig. 3f demonstrates that LDV emissions of $\mathrm{NO}_{\mathrm{x}}$ per unit fuel show strong dependence of driving conditions over the range of hour averages in the afternoon. This indicates congestion episodes, represented by the high standard deviations of LDV traffic flows (Fig. 3d).

The background-corrected $\left[\mathrm{NO}_{\mathrm{x}}\right]$ versus $[\mathrm{CO}]$ concentrations, measured in TRA and TJQ tunnels, is shown in Fig. $4 \mathrm{a}, \mathrm{b}$. The frequency distribution of $\left[\mathrm{NO}_{\mathrm{x}}\right]$ to $[\mathrm{CO}]$ ratio in TRA is relatively skewed (skewness $\approx 3.3$ ). The skewness is likely due to the high variability of a mixed vehicle emission source, fleet composed by a mixture of HDVs and LDVs, which depends upon parameters such as vehicle age, engine type, fuel type (ethanol, diesel, gasoline), maintenance and driving conditions (Perez-Martinez 2012). Thus, as expected, relatively few, more polluting HDVs (high $\mathrm{NO}_{\mathrm{x}}$ and $\mathrm{PM}_{10}$ emitters) are accounting for a significant percentage of the total emissions (Chirico et al. 2011). In Fig. 4a, the presence of HDVs increases the mean $\left[\mathrm{NO}_{\mathrm{x}}\right]$ versus $[\mathrm{CO}]$ ratio since $\mathrm{HDV}$ s emit more $\mathrm{NO}_{\mathrm{x}}$ per $\mathrm{CO}$ unit. There is a significant difference between the ratios based on the two tunnel measurements, with the TJQ results being normal distributed (Fig. $4 \mathrm{~b}$, skewness $\approx 0.0$ ). This distribution is centered to $0.05 \pm 0.01$ (mean and $\mathrm{SD}$ ), consistent with the expectation that at homogeneous fleet, LDVs emit a large fraction of the total fleet, impacts the tunnel measurements. Also shown in Fig. $4 \mathrm{c}$ is $\Delta\left[\mathrm{PM}_{10}\right] / \Delta\left[\mathrm{CO}_{2}\right]$ versus $\Delta\left[\mathrm{NO}_{\mathrm{x}}\right] / \Delta[\mathrm{CO}]$ frequency distributions for the different HDVs events (measured by the 


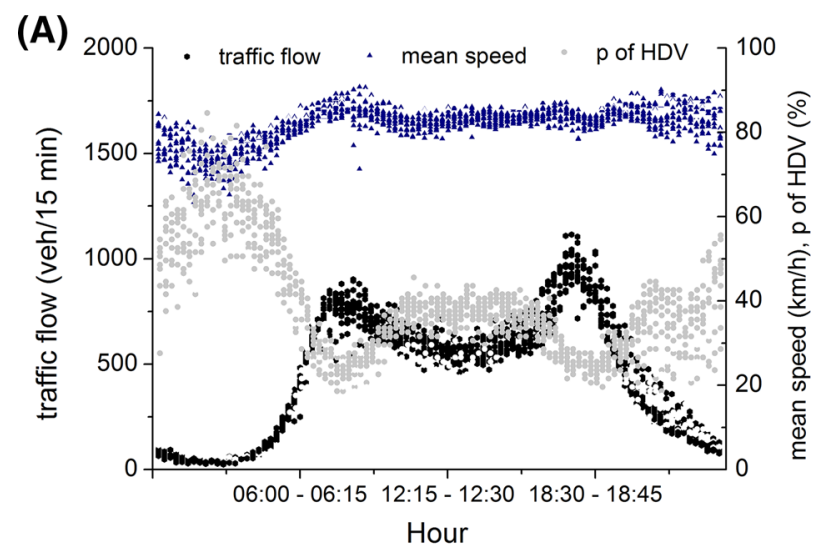

(B)
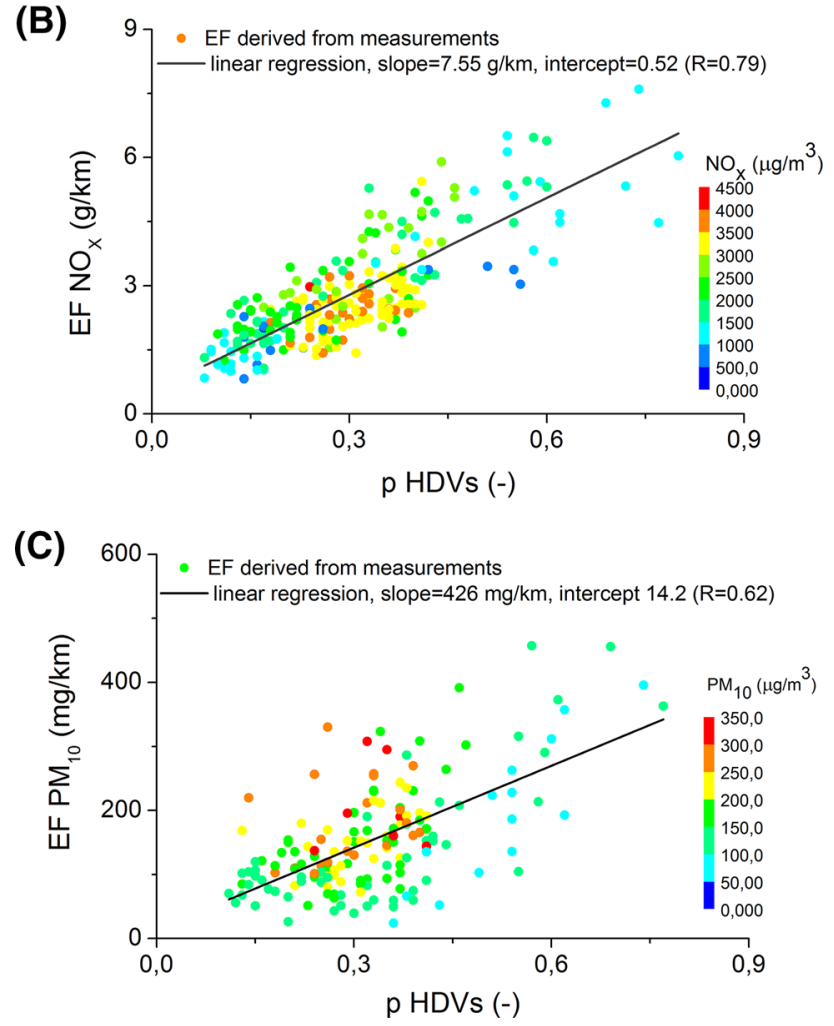

Fig. 5 Average vehicle speed, percentage of heavy-duty vehicles in the fleet and total traffic volume as a function of time of day (a). Emission factors for $\mathrm{NO}_{\mathrm{X}}(\mathbf{b})$ and $\mathrm{PM}_{10}(\mathbf{c})$, estimated by Eqs. (1-7), versus the percentage of HDVs. Note the two linear fits $(\mathbf{a}, \mathbf{b})$ reported the Pearson correlation coefficients $(R)$, the slopes and the intercepts

percentage of HDVs) in TRA. The background-corrected concentrations of $\mathrm{PM}_{10}$, normalized by the $\mathrm{CO}_{2}$ concentration to account for the fuel consumption, decrease with decreasing $\mathrm{NO}_{\mathrm{x}} / \mathrm{CO}$ ratios: for low $\mathrm{NO}_{\mathrm{x}} / \mathrm{CO}$ values, the $\mathrm{PM}_{10} / \mathrm{CO}_{2}$ values decrease by a factor of $\approx 3$ and the map scale of the plots indicates that at the same time, the percentage of HDVs decreases (Fig. 4c). HDVs emit more $\mathrm{PM}_{10}$ than LDVs, and high percentage of HDVs implies high concentrations of $\mathrm{PM}_{10}$ per $\mathrm{CO}_{2}$ unit. Analyzing also the distribution of the $\Delta\left[\mathrm{PM}_{10}\right] / \Delta\left[\mathrm{CO}_{2}\right]$ with respect to
$\Delta\left[\mathrm{NO}_{\mathrm{x}}\right] / \Delta[\mathrm{CO}]$ ratios for the different vehicle events (measured by the total traffic per hour) in TJQ (Fig. 4d), we can see that lower $\mathrm{NO}_{\mathrm{x}}$ vehicle emissions per $\mathrm{CO}$ unit and $\mathrm{PM}_{10}$ vehicle emissions per $\mathrm{CO}_{2}$ unit are related to high LDV traffic. Vehicle speeds decrease due to increased LDV traffic, and higher traffic leads to higher $\mathrm{CO}_{2}$ (fuel consumption) and CO LDV emissions. The distribution of the Fig. $4 \mathrm{c}$ corresponding to TRA is also more skewed compared to TJQ.

The background-corrected concentrations of $\mathrm{PM}_{10}$ vehicle emissions, normalized by the $\mathrm{CO}$ concentration to account for dilution of urban background air, are related to the percentage of HDVs in TRA $(R=0.68)$; the $\Delta\left[\mathrm{PM}_{10}\right] /$ $\Delta[\mathrm{CO}]$ ratios were $0.17 \pm 0.05$ for $20 \%$ of HDVs and $\mathrm{PM}_{10}$ concentrations inside the tunnel of $148 \pm 33 \mu \mathrm{g} \mathrm{m}^{-3}$; these ratios were two-three times higher, from 0.20 to 0.29 , for $50 \%$ of HDVs and lower $\mathrm{PM}_{10}$ concentrations of $90-120 \mu \mathrm{g} \mathrm{m}^{-3}$. It seems evident the impact of the fleet composition, expressed as percentage of HDVs, on the $\Delta\left[\mathrm{PM}_{10}\right] / \Delta[\mathrm{CO}]$ ratios. In TJQ, it was not observed strong relationships between $\Delta\left[\mathrm{PM}_{10}\right] /$ $\Delta[\mathrm{CO}]$ ratios and total traffic. In both tunnels, strong relations between traffic and inside tunnel parametersvehicle speed, traffic flow, air velocity and percentage of HDVs (Fig. 1; Table 1) - and pollutant concentrations (Fig. 2) were observed. Thus, in TRA, an increase in the traffic flow, and also a decrease in the number of HDVs, resulted in an increase in the air velocity inside the tunnel. At a traffic flow of about 250 vehicles per $15 \mathrm{~min}$, an increase in the vehicle speed is observed, with speeds increasing from 70 to $80-90 \mathrm{~km} \mathrm{~h}^{-1}$ (Fig. 5a). The periods with higher speeds correspond to the daytime with higher $\mathrm{NO}_{\mathrm{x}}\left(\geq 3,000 \mu \mathrm{g} \mathrm{m}^{-3}\right)$ and $\mathrm{PM}_{10}$ concentrations $\left(\geq 200 \mu \mathrm{g} \mathrm{m}^{-3}\right.$ ) (Fig. 5b, c). Higher concentrations of these pollutants during peak hours corresponded to higher air velocities. In TJQ, the air velocity also increases with the traffic flow, but with the difference that higher concentrations during peak hours, where a traffic flow of about 2,500 vehicles per hour, did not correspond to higher air velocities. One explanation of this could be the existence of stagnant air in the tunnel due to traffic congestion episodes.

Emission factor estimates and literature comparison

The EFs of $\mathrm{NO}_{\mathrm{x}}$ and $\mathrm{PM}_{10}$, as obtained with Eqs. 1 and 4, are shown in Fig. 5 against the percentage of HDVs, indicating an increase in the EFs with the fraction of HDVs in TRA. $\mathrm{NO}_{\mathrm{x}}$ (Fig. 5b) and $\mathrm{PM}_{10}$ (Fig. 5c) measurements are mapped by the $\mathrm{NO}_{\mathrm{x}}$ and $\mathrm{PM}_{10}$ concentrations inside the tunnel. At $25 \%$ of HDVs, corresponding to the traffic peak hours (Fig. 5a), the EFs of $\mathrm{NO}_{\mathrm{x}}$ and $\mathrm{PM}_{10}$ varied between $\approx 1.5$ and $\approx 4.0 \mathrm{~g} \mathrm{~km}^{-1}$ and $\approx 15$ and $\approx 450 \mathrm{mg} \mathrm{km}^{-1}$, 
respectively. During the central hours of the day, the color mapping according to the concentrations shows that higher EFs of $\mathrm{NO}_{\mathrm{x}}$ and $\mathrm{PM}_{10}$ are related to higher concentrations and higher traffic flow of LDVs. Off peak hours, corresponding to higher percentages of HDVs (and average speed lower than $80 \mathrm{~km} \mathrm{~h}^{-1}$ ), are related to lower concentrations and lower traffic flow of LDVs. Considering the rush hours (9:00 am and 17:00 pm) with $658 \pm 202$ HDVs and 1,902 \pm 485 LDVs per hour (and average speed over $80 \mathrm{~km} \mathrm{~h}^{-1}$ ), we can estimate that $94.8 \pm 2.4$ and $87.5 \pm 6.2 \%$ of the total $\mathrm{NO}_{\mathrm{x}}$ and $\mathrm{PM}_{10}$ emitted per driven kilometer inside the tunnel by all the vehicles is due to HDVs. HDVs emit much more $\mathrm{NO}_{\mathrm{x}}$ and $\mathrm{PM}_{10}$ per driven kilometer and a $25 \%$ fraction of HDVs significantly affect the total $\mathrm{NO}_{\mathrm{x}}$ and $\mathrm{PM}_{10}$ vehicle emissions.

There are significant linear correlations between the EFs of $\mathrm{NO}_{\mathrm{x}}$ and $\mathrm{PM}_{10}$ and the percentage of HDVs ( $R$ equal to 0.79 and 0.62 for $\mathrm{NO}_{\mathrm{x}}$ and $\mathrm{PM}_{10}$, respectively, Fig. 5b, c). The linear regression analysis reflects an estimation of the EFs for HDVs (slope of the regression) and LDVs (intercept). The EFs of $\mathrm{NO}_{\mathrm{x}}$ values were $7.5 \pm 0.4$ and $0.5 \pm 0.1 \mathrm{~g} \mathrm{~km}^{-1}$, for HDVs and LDVs, respectively. Analogously, the EFs of $\mathrm{PM}_{10}$ values were $426 \pm 41$ (HDVs) and $14.2 \pm 14.5 \mathrm{mg} \mathrm{km}^{-1}$ (LDVs). The results show the patterns reported in other studies where the $\mathrm{NO}_{\mathrm{x}}$ and $\mathrm{PM}_{10}$ emissions from HDVs were by and order of magnitude or more higher than the LDVs emissions (Chirico et al. 2011). There are differences between the two pollutant species (reflected by the correlation coefficient and the variability with concentrations). Therefore, $\mathrm{PM}_{10}$ experiments a concentration effect due to partitioning during rush hours and higher EFs are associated with higher concentrations (Fig. 5c). However, the values of EFs of $\mathrm{NO}_{\mathrm{X}}$ versus the percentage of HDVs (Fig. 5b) show little dispersion with concentration, excluding different driving patterns and vehicle speeds as a source of the former $\mathrm{EFs}\left(\mathrm{PM}_{10}\right)$ dispersion. Thus, more accelerations and decelerations and higher speeds (over $80 \mathrm{~km} \mathrm{~h}^{-1}$ ) during heavy traffic periods and more constant vehicle speed (lower than $80 \mathrm{~km} \mathrm{~h}^{-1}$ ) for situations without traffic and higher percentages of HDVs (Fig. 5a) can explain the dispersion of EFs $\left(\mathrm{PM}_{10}\right)$.

Emission factors were calculated for LDVs and HDVs according to the methodology proposed (Eqs. 1-7). The vehicles using TJQ had cleaner technology than in other parts of the city related to the higher income of the population in the area, and, on the other hand, HDVs using TRA were old trucks. Thus, the emission factors presented in this paper may underestimate the emission of LDVs and overestimate the emission of HDVs. The fuel-based emission factors measured during this study (mixed fleet and HDV in TRA and LDV in TJQ) are presented in $\mathrm{g} \mathrm{km}^{-1}$ in Table 4 (except for $\mathrm{PM}_{2.5}$, expressed in $\mathrm{mg} \mathrm{km}^{-1}$ ), together with the values from a past field study (Martins et al. 2006). The values of EFs estimated for $\mathrm{CO}$ and $\mathrm{NO}_{\mathrm{x}}$ for LDVs in the present work show significant reduction when compared the values of EFs calculated in the experiment conducted in 2004 (Martins et al. 2006). The reduction ratio was 2.2 times for $\mathrm{CO}$ and 3.2 for $\mathrm{NO}_{\mathrm{x}}$. In recent decades, control of $\mathrm{NO}_{\mathrm{x}}$ emissions from gasoline burning cars has been experienced by use of catalytic converters in the exhaust system of vehicles. Modern three-way catalysts use platinum and rhodium surfaces, changing the nitrogen oxides back to nitrogen and oxygen elemental (Heck and Farrauto 2001). Similarly, for HDVs, the values of EFs showed significantly reduction for $\mathrm{CO}$ and $\mathrm{NO}_{\mathrm{x}}$. Comparing the EFs of LDVs and HDVs, we observed the highest contribution of light vehicles to $\mathrm{CO}$ emissions; this was expected since $\mathrm{CO}$ emissions originate from gasoline vehicles are higher than for diesel vehicles (Heywood 1998). The marked difference between the two tunnels in terms of the concentration of $\mathrm{NO}_{\mathrm{x}}$ and $\mathrm{PM}_{10}$ indicates the significant emissions of such pollutants by HDVs. The emission factors for these two pollutants were shown to be higher for HDVs.

Table 4 Emission factors $\left(\mathrm{g} \mathrm{km}^{-1}, \mathrm{~g} \mathrm{~kg}^{-1}\right.$ of fuel burned) from 2011 in comparison with values calculated in 2004 study (mean \pm SD)

\begin{tabular}{lllllll}
\hline Vehicle & Local measured & $\begin{array}{l}\text { Fuel } \\
\left(\mathrm{km} \mathrm{kg}^{-1}\right)\end{array}$ & $\begin{array}{l}\mathrm{CO}\left(\mathrm{g} \mathrm{km}^{-1}\right) \\
\left(\mathrm{g} \mathrm{kg}^{-1}\right)\end{array}$ & $\begin{array}{l}\mathrm{NO}_{\mathrm{x}}\left(\mathrm{g} \mathrm{km}^{-1}\right) \\
\left(\mathrm{g} \mathrm{kg}^{-1}\right)\end{array}$ & $\begin{array}{l}\mathrm{PM}_{2.5}\left(\mathrm{mg} \mathrm{km}^{-1}\right) \\
\left(\mathrm{g} \mathrm{kg}^{-1}\right)^{\mathrm{b}}\end{array}$ & $\begin{array}{l}\mathrm{CO}_{2}\left(\mathrm{~g} \mathrm{~km}^{-1}\right) \\
\left(\mathrm{g} \mathrm{kg}^{-1}\right)\end{array}$ \\
\hline LDV & TJQ (2011) & $13.7 \pm 18.4$ & $5.8 \pm 3.8$ & $0.3 \pm 0.2$ & $20 \pm 8$ & $219 \pm 165$ \\
& & & $81.5 \pm 41.5$ & $4.2 \pm 1.7$ & $0.3 \pm 0.1$ & $2,964 \pm 96$ \\
HDV & TRA (2011) & $2.2 \pm 2.7$ & $3.6 \pm 1.5$ & $9.2 \pm 2.7$ & $277 \pm 108$ & $1,422 \pm 1,179$ \\
& & & $7.9 \pm 4.1$ & $25.8 \pm 7.6$ & $0.7 \pm 0.3$ & $3,177 \pm 9$ \\
LDV & TJQ (2004) (Martins et al. & n.d. & $14.6 \pm 2.3$ & $1.6 \pm 0.3$ & n.d. & n.d. \\
& 2006) & & n.d. & n.d. & n.d. & n.d. \\
HDV & TMM (2004) (Martins et al. & n.d. & $20.6 \pm 4.7$ & $22.3 \pm 9.8$ & n.d. & n.d. \\
& 2006) & & n.d. & n.d. & n.d. & n.d. \\
\hline
\end{tabular}

\footnotetext{
a Tunnel María Maluf, São Paulo (2004)

b Results using the gravimetric measurement device (Partisol 2000-D)
} 

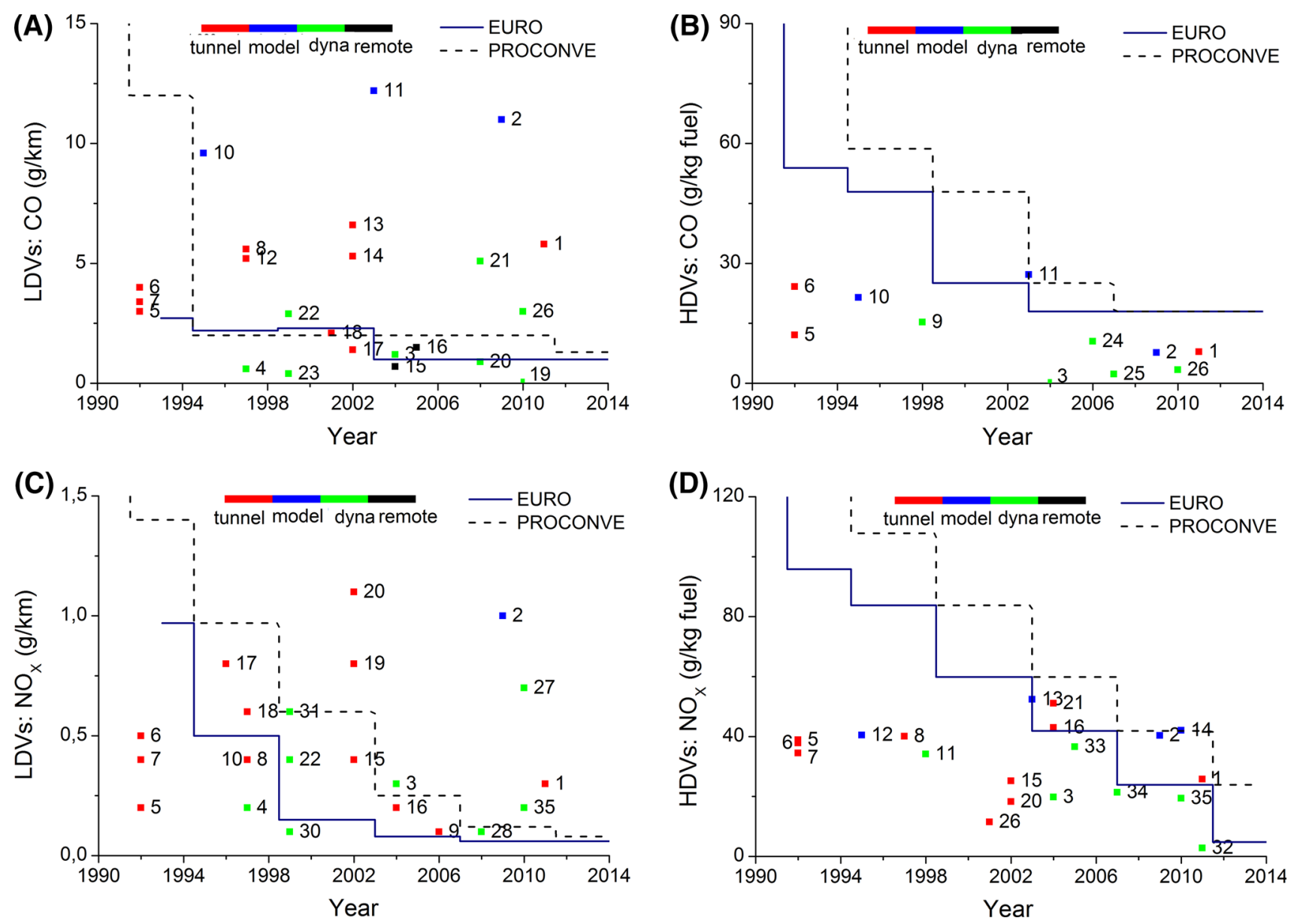

The use of a non-gravimetric measurement devices and measurement of $\mathrm{PM}_{10}$ instead of $\mathrm{PM}_{2.5}$ has potential restrictions and could lead to extraordinary high EFs (particularly for LDVs) due to the influence of re-suspended road dust. In this case, observed $\mathrm{PM}_{10}$ concentration levels are a major concern and restrictions can be mitigated using a gravimetric $\mathrm{PM}_{2.5}$ sampler (as the Partisol 2000-D, Table 2). In Table 4, the values of the EFs estimated for $\mathrm{PM}_{2.5}$ were $277 \pm 108$ (HDVs) and $20.2 \pm 8.4 \mathrm{mg} \mathrm{km}^{-1}$ (LDVs). In TRA, about $80 \%$ of total $\mathrm{PM}$ concentrations inside the tunnel were due to $\mathrm{PM}_{2.5}$ and the EFs $\left(\mathrm{PM}_{10}\right)$ obtained for the HDVs using the nongravimetric sampler $\left(\approx 297 \pm 245 \mathrm{mg} \mathrm{km}^{-1}\right)$ approximate well to the values estimated using the concentration levels of the gravimetric device. The EFs $\left(\mathrm{PM}_{10}\right)$ for LDVs in TRA (determined by the intercept of the regression of Fig. $5 \mathrm{c}, 14.2 \pm 14.5 \mathrm{mg} \mathrm{km}^{-1}$ ) approximate to the values of $\mathrm{PM}_{2.5}$ in TJQ. The higher values in TJQ could be due to the presence of traffic congestion episodes.

The Brazilian vehicle fleet is fundamentally different from the European and US fleet. For this reason, we decide to include some results from the European and US

emission factor studies that provide references for comparison of the relative emission rates of Brazilian vehicles. The fuel-based $\mathrm{CO}$ and $\mathrm{NO}_{\mathrm{x}}$ emission factors measured during this study (LDVs and HDVs) are shown in Fig. 6, together with the estimates from other reviewed studies, reported as individual mean values (data points). Figure 6 shows reported values of $\mathrm{CO}$ and $\mathrm{NO}_{\mathrm{x}}$ emission factors from on-road LDVs and HDVs, expressed by grams of pollutant per driven kilometer (LDVs, Fig. 6a and Fig. 6c) and by grams of pollutant per kilogram of consumed fuel (HDVs, Fig. 6b and Fig. 6d), by reference year. In Fig. 6 plots, the study 1 represents the mean EFs computed with the measured parameters of Eqs. 1-7 using the TRA (HDVs) and TJQ (LDVs) data. These plots illustrate the overall decreased on-road $\mathrm{CO}$ and $\mathrm{NO}_{\mathrm{x}}$ emissions from the late 1990s reference years, since the implementation of the consent decrees: represented by the European EURO and Brazilian PROCONVE emission standards. Figure 6 also displays the vehicle engine dynamometer certification standards for new LDV and HDV engines, represented as step horizontal lines. As can be seen in Fig. 6, although the consent decrees did have an effect in reducing on-road 
4Fig. 6 Mean LDVs kilometer-driven and HDVs fuel-based CO and $\mathrm{NO}_{\mathrm{x}}$ emission factors from this study (LDVs: a-c; HDVs: b-d), compared with reviewed literature (reported mean values) and the IVEderived emission factors optimized for São Paulo, plotted versus study reference year. The step horizontal lines represent the new vehicle engine certification standards, in $\mathrm{g} \mathrm{km}^{-1}$ (LDVs) and in $\mathrm{g} \mathrm{kg}^{-1}$-fuel (HDVs), for Europe (EURO, solid lines) and Brazil (PROCONVE, dotted lines). Note (1), references used in $\mathbf{a}$ and $\mathbf{b}(\mathrm{CO}):{ }^{1}$ this study; ${ }^{2}$ Perez-Martinez (2012), bottom-up modeling from the road transport in Spain; ${ }^{3}$ Lents et al. (2007), international vehicle emissions (IVE) obtained from chassis dynamometer analysis under urban conditions and corrected for driving patterns in São Paulo; ${ }^{4}$ Becker et al. (1999), dynamometer study of mixture of gasoline and diesel vehicles; ${ }^{5}$ Pierson et al. (1996), summary of studies in the Tuscarora mountain tunnel (Pennsylvania, PA, USA), real-world automotive emissions from gasoline-powered vehicles; ${ }^{6}$ Pierson et al. (1996), Fort McHenry tunnel (Baltimore, MD, USA), uphill (3.3\%) traffic emissions; ${ }^{7}$ Pierson et al. (1996), Fort McHenry tunnel (Baltimore, MD, USA), downhill (1.8 \%) traffic emissions; ${ }^{8}$ Kirchstetter et al. (1999), Caldecott tunnel (San Francisco, CA, USA), uphill (4.5\%) emissions; ${ }^{9}$ Yanowitz et al. (2000), in-use mean emissions from heavy-duty diesel vehicles; ${ }^{10}$ Burgard et al. (2006), HDVs from 10,000 to $>100,000$ pound weight (pound equivalent to 0,453 kilograms) and with 10,000 to $1,000,000$ miles (mile equivalent to 1.61 kilometer); ${ }^{11}$ Perez-Martinez and Vassallo-Magro (2012), topdown modeling and Euro Emission Pollutant Standards (EMPS); ${ }^{12}$ Weingartner et al. (1997), LDV emissions in the Caldecott tunnel; ${ }^{13}$ McGaughey et al. (2004), LDV emissions in the Washburn tunnel (TX, USA); ${ }^{14}$ Kristensson et al. (2004), emissions in the Soderleds tunnel (Stockholm, Sweden); ${ }^{15}$ Bishop and Stedman (2008), site plot (Phoenix, Arizona, USA), uphill (1.3\%) LDV emissions; ${ }^{16}$ Bishop and Stedman (2008), site plot (West Los Angeles, CA, USA), uphill (2.0 \%) LDV emissions; ${ }^{17}$ Colberg et al. (2005a), Gubrist tunnel (Switzerland), uphill $(1.25 \%)$ mixed fleet emissions (20\% HDVs) during weekdays at a driving speed of $90 \mathrm{~km} \mathrm{~h}^{-1} ;{ }^{18}$ Colberg et al. (2005b), Lundby tunnel (Sweden), uphill $(0.50 \%)$ vehicle emissions during weekdays at $75 \mathrm{~km} \mathrm{~h}^{-1} ;{ }^{19}$ OASIS (2011), emissions of an EURO III diesel car, vehicle-specific power of $12 \mathrm{~W} \mathrm{~kg}^{-1}$, speed of $100 \mathrm{~km} \mathrm{~h}^{-1}$ in a trip from Madrid to Villacastil (Spain); ${ }^{20}$ EMEP (2009), results of the COPERT model based on dynamometer study of EURO III gasoline LDV at $90 \mathrm{~km} \mathrm{~h}^{-1} ;{ }^{21}$ Achour et al. (2011), dynamometer study of EURO III gasoline car; ${ }^{22}$ Pujadas et al. (2004), dynamometer study of EURO II gasoline car; ${ }^{23}$ Joumard et al. (2003), dynamometer studies of EURO II LDVs and EURO II 3.5 t vans; ${ }^{24}$ Zhai et al. (2008), HDV emission rates based on dynamometer study at principal arterials; ${ }^{25}$ López et al. (2009), dynamometer study of EURO IV urban bus; ${ }^{26}$ CETESB (2012), tile pipe emissions; Note (2), references used in $\mathbf{c}$ and d $\left(\mathrm{NO}_{\mathrm{x}}\right):{ }^{1}$ this study; ${ }^{2}$ Perez-Martinez (2012); ${ }^{3}$ Lents et al. (2007); ${ }^{4}$ Becker et al. (1999); ${ }^{5,6,7}$ Pierson et al. (1996); ${ }^{8}$ Kirchstetter et al. (1999); ${ }^{9}$ Ban-Weiss et al. (2008); ${ }^{10}$ Ban-Weiss et al. (2008); ${ }^{11}$ Yanowitz et al. (2000); ${ }^{12}$ Burgard et al. (2006); ${ }^{13}$ Perez-Martinez and Vassallo-Magro (2012); ${ }^{14}$ Wang et al. (2012), Chase dynamometer study in Chongqing (China) based on results of 2010 level 124 trucks; ${ }^{15}$ Colberg et al. (2005b); ${ }^{16}$ Grieshop et al. (2006), results of tunnel experiments; ${ }^{17}$ Gillies et al. (2001), measurements of mixed LDVs and HDVs in the Sepúlveda tunnel (Los Angeles, CA, USA); ${ }^{18}$ Weingartner et al. (1997); ${ }^{19}$ McGaughey et al. (2004); ${ }^{20}$ Kristensson et al. (2004); ${ }^{21}$ SanchezCcoyllo et al. (2009), LDVs emissions in the Janio Quadros and Maria Maluf tunnels (São Paulo, Brazil); ${ }^{22}$ Kean et al. (2003), uphill emissions of HDVs from dynamometer studies, specific power of $12 \mathrm{~W} \mathrm{~kg}^{-1}$ and speed of $75 \mathrm{~km} \mathrm{~h}^{-1} ;{ }^{23}$ Harley et al. (2005), Caldecott tunnel (San Francisco, CA, USA), LDVs emissions; ${ }^{24,25}$ Bishop and Stedman (2008); ${ }^{26}$ Colberg et al. (2005b); ${ }^{27}$ OASIS (2011); ${ }^{28}$ EMEP (2009); ${ }^{29}$ Achour et al. (2011); ${ }^{30}$ Pujadas et al. (2004); ${ }^{31}$ Joumard et al. (2003); ${ }^{32}$ Franco et al. (2013), ARTEMIS 300 database and dynamometer study of EURO IV HDV on an articulated motorway Art-MW-150-3hot (15.3); ${ }^{33}$ Zhai et al. (2008); ${ }^{34}$ López et al. (2009); ${ }^{35}$ CETESB (2012)
LDVs $\mathrm{CO}$ and $\mathrm{NO}_{\mathrm{x}}$ emissions, they are above their engine emission standards at the most of the studies reviewed (including this work). For HDVs, the EFs reviewed are under their engine emission standards. Figure 6d also shows that 1990s and 2004-2006 study year references have similar $\mathrm{NO}_{\mathrm{x}}$ emission factors, even though the certificated emission standards have decreased fourfold. Similarly, 2007-2011 study year references are based on newer engines that produce more power per kilogram of fuel used, bringing $\mathrm{NO}_{\mathrm{x}}$ emission factors closer to the standards.

Figure 6 reported on-road emission factors by year of measurement, pollutant $\left(\mathrm{CO}\right.$ and $\left.\mathrm{NO}_{\mathrm{x}}\right)$ and type of study. The figure presents analysis of 35 studies dealing with the determination of the emission factors of various types of traffic emission models and employing different methodologies: measurements in tunnels, bottom-up and top-down modeling, dynamometer laboratory tests and remote sensing. The mean EFs (LDV) and EFs (HDV) - approximately $5.8 \pm 3.8 \mathrm{~g} \mathrm{CO} \mathrm{km}^{-1}$ (LDV), $0.3 \pm 0.2 \mathrm{~g} \mathrm{NO}_{\mathrm{x}} \mathrm{km}^{-1}$ (LDV), $\quad 7.9 \pm 4.1 \mathrm{~g} \mathrm{CO} \mathrm{kg}^{-1}$ of fuel (HDV) and $25.8 \pm 7.6 \mathrm{~g} \mathrm{NO}_{\mathrm{x}} \mathrm{kg}^{-1}$ of fuel (HDV)-estimated in this study are directly comparable to other reported average values. Most of the reviewed mean values fall between the mean and standard deviation of the EF values determined here, especially those from recent studies and from HDVs. Some high EFs for LDVs have been reported in past studies. However, continued LDV's EFs measurements at similar locations over the subsequent years demonstrate a significant reduction in the LDV's EFs. The larger variation of LDV predictions, compared with HDV EF estimates, may be associated with different definitions between models and emission standards (i.e., measurement methodologies, driving conditions, non-exhaust contribution and life cycle analysis). The minor deviations of study predictions to emission standards, when the studies are categorized according to model technique, correspond to dynamometer studies (especially for LDVs). When the studies are based on tunnel measurements of LDV traffic, $\mathrm{CO}$ and $\mathrm{NO}_{\mathrm{x}}$ EFs are overestimated after the middle 1990s. Note also that LDV and HDV emission standards shown in this study are for comparisons only, since they are based on tests performed on engine dynamometers under specific conditions that may be not include real driving operations and conditions.

\section{Conclusion}

Gas species $\left(\mathrm{CO}, \mathrm{NO}_{\mathrm{x}}, \mathrm{CO}_{2}\right)$ and $\mathrm{PM}_{10}$ were measured in TJQ and TRA tunnels during 2 weeks in May and July 2011. Concentrations had a typical diurnal profile with two concentration peaks related to vehicle traffic in the morning 
peak hour (6:00-9:00, 3,090 vehicles $\mathrm{h}^{-1}$ in TRA) and in the afternoon peak hour (16:00-19:00, 3,800 vehicles $h^{-1}$ in TJQ) on working days. Peak traffic flow corresponds to the highest value of the standard deviation of the mean, while the fraction of HDV at peak volume is generally lower and indicates congestion episodes, especially at TJQ. In TRA, the $\mathrm{NO}_{\mathrm{x}}$ and $\mathrm{PM}_{10}$ concentrations were higher on working days, when the percentage of HDVs $(p)$ was $38.7 \pm 4.3 \%$, while on weekends with $p 20.1 \pm 7.1 \%$, the concentrations fell by a factor of 2 (while the traffic did substantially decrease on weekends). The $\mathrm{NO}_{\mathrm{x}}$ and $\mathrm{PM}_{10}$ background-corrected concentrations were normalized to the $\mathrm{CO}_{2}$ concentration, to account for the fuel consumption in the tunnels, and in TJQ were higher when the $\mathrm{NO}_{\mathrm{x}} / \mathrm{CO}$ and $\mathrm{NO}_{\mathrm{x}} / \mathrm{PM}_{10}$ had maximum values. In TRA, high $\mathrm{NO}_{\mathrm{x}} /$ $\mathrm{CO}$ and $\mathrm{NO}_{\mathrm{x}} / \mathrm{PM}_{10}$ ratios were associated with diesel vehicle emissions from $\mathrm{HDV}$ s and $\mathrm{NO}_{\mathrm{x}} / \mathrm{CO}_{2}$ and $\mathrm{PM}_{10} /$ $\mathrm{CO}_{2}$ ratios presented less variations. In TJQ $\mathrm{NO}_{x}$, emissions per unit fuel show strong dependence on traffic conditions including congestion episodes. The difference in the two tunnels demonstrates the advantage of using $\mathrm{NO}_{\mathrm{x}} /$ $\mathrm{CO}_{2}$ rather than $\mathrm{NO}_{\mathrm{x}} / \mathrm{CO}$ ratios especially where fleet composition is changing from HDV to LDV traffic as in TRA. In TRA, more polluting HDVs are responsible for a significant percentage of the total emissions and in TJQ LDVs emit a large fraction of the total fleet emissions.

The estimation of the EFs depends on the time periods considered. Although weekday, weekend and high traffic periods are averaged, the standard deviation measures the uncertainty of the estimates and reflects different traffic conditions: traffic volumes, percentage of HDV and speed. The EFs estimated for $\mathrm{CO}_{2}, \mathrm{CO}, \mathrm{NO}_{\mathrm{x}}$ and $\mathrm{PM}_{10}$, and the $\mathrm{NO}_{\mathrm{x}} / \mathrm{CO}$ and $\mathrm{PM}_{10} / \mathrm{CO}$ ratios were strongly affected by the traffic and proportion of HDVs. EFs for HDVs and LDVs were calculated in TRA and TJQ tunnels. The $\mathrm{EF}\left(\mathrm{NO}_{\mathrm{x}}\right)_{\mathrm{LDV}}$ was $0.3 \pm 0.2 \mathrm{~g} \mathrm{~km}^{-1}$ and the $\mathrm{EF}\left(\mathrm{NO}_{\mathrm{x}}\right)_{\mathrm{HDV}}$ was $9.2 \pm 2.7 \mathrm{~g} \mathrm{~km}^{-1}$ for a temperature of $20-25{ }^{\circ} \mathrm{C}$ inside the tunnels. Similarly, the $\mathrm{EF}\left(\mathrm{PM}_{10}\right)_{\mathrm{LDV}}$ was $20 \pm 8 \mathrm{mg} \mathrm{km}^{-1}$ and the $\mathrm{EF}\left(\mathrm{PM}_{10}\right)_{\mathrm{HDV}}$ was $277 \pm 108 \mathrm{mg} \mathrm{km}^{-1}$ for TRA and TJQ, respectively. Driving conditions and traffic composition were quite different in the two measurement tunnels. In TRA, the values of EFs of $\mathrm{PM}_{10}$ experiment a concentration effect due to partitioning and are associated with higher concentrations, oppositely to the values of $\mathrm{NO}_{\mathrm{x}}$ that show little dispersion with concentration. In TJQ, the EF estimates presented in this paper are directly applicable to urban ambient conditions because they derived from $\mathrm{PM}_{10}$ concentrations that are a factor of only 2.5-3.5 higher than urban concentrations.

The present study results have implications for $\mathrm{NO}_{\mathrm{x}}$ and $\mathrm{CO}$ measurements and emission standards regulations. Although it is difficult to find out differences between pollutant species, vehicle categories and methodologies, when comparing the EF estimates with the emission standards, an overestimation for $\mathrm{CO}$ and $\mathrm{NO}_{\mathrm{x}}$ was established for LDVs and practically for all estimation techniques (EF estimates have been moving from underestimation to overestimation since the middle 1990s.). In the case of HDVs, reviewed studies (including this work) always underestimate the EFs both for $\mathrm{CO}$ and $\mathrm{NO}_{\mathrm{x}}$. The pollutant standards of HDVs, especially for $\mathrm{NO}_{\mathrm{X}}$, were established extremely high and did not reflect properly the commitment and capacity of the industry to reduce the emissions. The deviations were corrected during last years. Oppositely, the standards of the LDVs were quite restrictive from the very beginning, especially for $\mathrm{CO}$, forcing the industry to reduce the emissions. The study results suggest that additional dynamometer, on-road measurements, and modeling estimates are needed in São Paulo in order to corroborate our findings and to improve the urban emission inventories in the MRSP in support of national and international policies, and estimates of impacts on external costs (health, environment and climate). Differences in vehicle age, engine size, driving pattern and meteorological conditions lead to differences in emission factors between the reviewed studies and this study.

Acknowledgments The authors thank the São Paulo State Research Foundation FAPESP, Research Program on Global Climate Change, for the financial support of this work (Processes 2008/58104-8 and 2011/18777-6). This study was also supported by the European Research Council (Grant 246565) in the framework of the Marie Curie UNITE project and through the program for contracting experienced researchers for scientific and technological research (COFUND, 7th Framework). We also thank the State Company for the Environment CETESB and the traffic engineering company CR for providing air quality and road traffic data.

\section{References}

Achour H, Carton JG, Olabi AG (2011) Estimating vehicle emissions from road transport, case study: Dublin City. Appl Energy 88(5):1957-1964

Alam JB, Wadud Z, Alam JB, Polak JW (2013) Energy demand and economic consequences of transport policy. Int J Environ Sci Technol 10:1075-1082

Altun S, Öner C (2013) Gaseous emission comparison of a compression-ignition engine fueled with different biodiesels. Int J Environ Sci Technol 10:371-376

Andrade MF, Miranda RM, Fornaro A, Kerr A, Oyama B, Andre PA, Saldiva $P$ (2012) Vehicle emissions and $\mathrm{PM}_{2.5}$ mass concentrations in six Brazilian cities. Air Qual Atmos Health 5(1):79-88

Ban-Weiss GA, McLaughlin JP, Harley RA, Lunden MM, Kirchstetter TW, Kean AJ, Strawa AW, Stevenson ED, Kendall GR (2008) Long-term changes in emissions of nitrogen oxides and particulate matter from on-road gasoline and diesel vehicles. Atmos Environ 42(2):220-232

Becker KH, Lörzer JC, Kurtenbach R, Wiesen P, Jensen TE, Wallington TJ (1999) Nitrous oxide $\left(\mathrm{N}_{2} \mathrm{O}\right)$ emissions from vehicles. Environ Sci Technol 33(22):4134-4139 
Belalcazar LC, Clappier A, Blond N, Flassak T, Eichhorn J (2010) An evaluation of the estimation of road traffic emission factors from tracer studies. Atmos Environ 44(31):3814-3822

Bishop GA, Stedman DH (2008) A decade of on-road emissions measurements. Environ Sci Technol 42(5):1651-1656

Burgard DA, Bishop GA, Stedman DH, Gessner VH, Daeschlein C (2006) Remote sensing of in-use heavy-duty diesel trucks. Environ Sci Technol 40(22):6938-6942

CETESB (2009) Relatório Anual de Qualidade do Ar no Estado de São Paulo 2009. Companhia de Tecnologia de Saneamento Ambiental, São Paulo

CETESB (2012) Relatório de Emissões Veiculares no Estado de São Paulo 2011. Companhia de Tecnologia de Saneamento Ambiental, São Paulo

CETESB (2013) Plano de Controle de Poluição Veicular do Estado de São Paulo 2011/2013. Companhia de Tecnologia de Saneamento Ambiental, São Paulo

Chang T, Rudy S (1990) Roadway tunnel air quality models. Environ Sci Technol 24:672-676

Chirico R, Prevot A, De Carlo PF, Heringa MF, Richter R, Weingartner E, Baltensperger U (2011) Aerosol and trace gas vehicle emission factors measured in a tunnel using an aerosol mass spectrometer and other on-line instrumentation. Atmos Environ 45:2182-2192

Colberg CA, Tona B, Catone G, Sangiorgio C, Stahel WA, Sturm P, Staehelin J (2005a) Statistical analysis of the vehicle pollutant emissions derived from several European road tunnel studies. Atmos Environ 39(13):2499-2511

Colberg CA, Tona B, Stahel WA, Meier M, Staehelin J (2005b) Comparison of a road traffic emission model (HBEFA) with emissions derived from measurements in the Gubrist road tunnel, Switzerland. Atmos Environ 39(26):4703-4714

Correa SM, Arbilla G (2008) Carbonyl emissions in diesel and biodiesel exhaust. Atmos Environ 42(4):769-775

EMEP (2009) Air pollutant emission inventory guidebook. European Environmental Agency EEA, Copenhagen

Franco V, Kousoulidou M, Muntean M, Ntziachristos L, Hausberger S, Dilara P (2013) Road vehicle emission factors development: a review. Atmos Environ 70:84-97

Gillies JA, Gertler AW, Sagebiel JC, Dippel WA (2001) On-road particulate matter $\left(\mathrm{PM}_{2.5}\right.$ and $\left.\mathrm{PM}_{10}\right)$ emissions in the Sepulveda Tunnel, Los Angeles, California. Environ Sci Technol 35(6): 1054-1063

Grieshop AP, Lipsky EM, Pekney NJ, Takahama S, Robinson AL (2006) Fine particle emission factors from vehicles in a highway tunnel: effects of fleet composition and season. Atmos Environ 40(Supplement 2):287-298

Harley RA, Marr LC, Lehner JK, Giddings SN (2005) Changes in motor vehicle emissions on diurnal to decadal time scales and effects on atmospheric composition. Environ Sci Technol 39(14):5356-5362

Heck RM, Farrauto RJ (2001) Automobile exhaust catalysts. Appli Catal A Gen 221(1-2):443-457

Heywood JR (1998) Pollutant formation and control in internal combustion engine fundamentals. McGraw-Hill Inc., New York

Huerta JI, Huertas ME, Díaz J (2012) Assessing precision and accuracy of atmospheric emission inventories. Int J Environ Sci Technol 9:195-202

Joumard R, André M, Vidon R, Tassel P (2003) Characterizing real unit emissions for light duty goods vehicles. Atmos Environ 37(37):5217-5225

Kean AJ, Harley RA, Kendall GR (2003) Effects of vehicle speed and engine load on motor vehicle emissions. Environ Sci Technol 37(17):3739-3746
Kirchstetter TW, Harley RA, Kreisberg NM, Stolzenburg MR, Hering SV (1999) On-road measurement of fine particle and nitrogen oxide emissions from light- and heavy-duty motor vehicles. Atmos Environ 33(18):2955-2968

Kirchstetter TW, Harley RA, Kreisberg NM, Stolzenburg MR, Hering SV (2002) Corrigendum to "On-road measurement of fine particle and nitrogen oxide emissions from light- and heavy-duty motor vehicles" [Atmospheric Environment 33 (18) (1999) 2955-2968]. Atmos Environ 36(39-40):6059

Kristensson A, Johansson C, Westerholm R, Swietlicki E, Gidhagen L, Wideqvist U, Vesely V (2004) Real-world traffic emission factors of gases and particles measured in a road tunnel in Stockholm, Sweden. Atmos Environ 38(5):657-673

Lents J, Nikkila N, Davis N, Canada M, Martinez H, Osses M (2007) A study of the emissions from diesel vehicles operating in São Paulo, Brazil and in Mexico City, Mexico. ISSRC (CA)

López JM, Jiménez F, Aparicio F, Flores N (2009) On-road emissions from urban buses with SCR + Urea and EGR + DPF systems using diesel and biodiesel. Transp Res D 14(1):1-5

Marr LC, Kirchstetter TW, Harley RA, Miguel AH, Hering SV, Hammond SK (1999) Characterizations of polycyclic aromatic hydrocarbons in motor vehicle fuels and exhaust emissions. Environ Sci Technol 33(18):3091-3099

Martins LD, Andrade MF, Freitas ED, Pretto A, Gatti LV, Albuquerque EL, Tomaz E, Guardani ML, Martins MHRB, Junior OMA (2006) Emission factors for gas-powered vehicles traveling through road tunnels in Sao Paulo, Brazil. Environ Sci Technol 40(21):6722-6729

McGaughey GR, Desai NR, Allen DT, Seila RL, Lonneman WA, Fraser MP, Harley RA, Pollack AK, Ivy JM, Price JH (2004) Analysis of motor vehicle emissions in a Houston tunnel during the Texas Air Quality Study 2000. Atmos Environ 38(20):3363-3372

Molina MJ, Molina LT (2004) Megacities and atmospheric pollution. J Air Waste Manag Assoc 54(6):644-680

OASIS (2011) Optimización de recursos energéticos. Operación de autopistas seguras, inteligentes y sostenibles. Madrid, Spain

Perez-Martinez PJ (2012) Energy consumption and emissions form the road transport in Spain: a conceptual approach. Transport 27(4):383-396

Perez-Martinez PJ, Vassallo-Magro JM (2012) Changes in the external costs of freight surface transport in Spain. Res Transp Econ 42(1):61-76

Pierson WR, Gertler AW, Robinson NF, Sagebiel JC, Zielinska B, Bishop GA, Stedman DH, Zweidinger RB, Ray WD (1996) Real-world automotive emissions - summary of studies in the Fort McHenry and Tuscarora Mountain tunnels. Atmos Environ 30(12):2233-2256

Pujadas ML, Núñez Plaza J, Bezares JC, Fernández JM (2004) Comparison between experimental and calculated vehicle idle emission factors for Madrid fleet. Sci Total Environ 334-335:133-140

Sanchez-Ccoyllo OR, Ynoue RY, Martins LD, Astolfo R, Miranda RM, Freitas ED, Borges AS, Fornaro A, Freitas H, Moreira A, Andrade MF (2009) Vehicular particulate matter emissions in road tunnels in Sao Paulo, Brazil. Environ Monit Assess 149(1-4):241-249

Wang X, Westerdahl D, Hu J, Wu Y, Yin H, Pan X, Zhang KM (2012) On-road diesel vehicle emission factors for nitrogen oxides and black carbon in two Chinese cities. Atmos Environ 46:45-55

Weingartner E, Keller C, Stahel WA, Burtscher H, Baltensperger U (1997) Aerosol emission in a road tunnel. Atmos Environ 31(3):451-462 
Yanowitz J, McCormick RL, Graboski MS (2000) In-use emissions from heavy-duty diesel vehicles. Environ Sci Technol 34(5):729-740
Zhai H, Frey HC, Rouphail NM (2008) A vehicle-specific power approach to speed- and facility-specific emissions estimates for diesel transit buses. Environ Sci Technol 42(21):7985-7991 